\title{
Bio-Char Characterization Produced from Walnut Shell Biomass through Slow Pyrolysis: Sustainable for Soil Amendment and an Alternate Bio-Fuel
}

\author{
Rami Alfattani ${ }^{1}$, Mudasir Akbar Shah ${ }^{2, *}$, Md Irfanul Haque Siddiqui ${ }^{3}{ }^{(}$, Masood Ashraf Ali $^{4}(\mathbb{C}$ \\ and Ibrahim A. Alnaser ${ }^{3}$ (D)
}

1 Department of Mechanical Engineering, Umm Al-Qura University, P.O. Box 715, Makkah 24224, Saudi Arabia; rafattni@uqu.edu.sa

2 Department of Chemical Engineering, Kombolcha Institute of Technology, Wollo University, Kombolcha 1145, Ethiopia

3 Department of Mechanical Engineering, King Saud University, Riyadh 11421, Saudi Arabia; msiddiqui2.c@ksu.edu.sa (M.I.H.S.); ianaser@ksu.edu.sa (I.A.A.)

4 Department of Industrial Engineering, College of Engineering, Prince Sattam Bin Abdulaziz University, Al-Kharj 16273, Saudi Arabia; mas.ali@psau.edu.sa

* Correspondence: shahmudasir22@nitsri.net

\section{check for}

updates

Citation: Alfattani, R.; Shah, M.A.; Siddiqui, M.I.H.; Ali, M.A.;

Alnaser, I.A. Bio-Char

Characterization Produced from Walnut Shell Biomass through Slow Pyrolysis: Sustainable for Soil Amendment and an Alternate Bio-Fuel. Energies 2022, 15, 1. https://doi.org/10.3390/en15010001

Academic Editor: Idiano D'Adamo

Received: 30 September 2021

Accepted: 15 December 2021

Published: 21 December 2021

Publisher's Note: MDPI stays neutral with regard to jurisdictional claims in published maps and institutional affiliations.

Copyright: (c) 2021 by the authors. Licensee MDPI, Basel, Switzerland. This article is an open access article distributed under the terms and conditions of the Creative Commons Attribution (CC BY) license (https:/ / creativecommons.org/licenses/by/ $4.0 /)$.

\begin{abstract}
Bio-char has the ability to isolate carbon in soils and concurrently improve plant growth and soil quality, high energy density and also it can be used as an adsorbent for water treatment. In the current work, the characteristics of four different types of bio-chars, obtained from slow pyrolysis at $375{ }^{\circ} \mathrm{C}$, produced from hard-, medium-, thin- and paper-shelled walnut residues have been studied. Bio-char properties such as proximate, ultimate analysis, heating values, surface area, $\mathrm{pH}$ values, thermal degradation behavior, morphological and crystalline nature and functional characterization using FTIR were determined. The pyrolytic behavior of bio-char is studied using thermogravimetric analysis (TGA) in an oxidizing atmosphere. SEM analysis confirmed morphological change and showed heterogeneous and rough texture structure. Crystalline nature of the bio-chars is established by X-ray powder diffraction (XRD) analysis. The maximum higher heating values (HHV), high fixed carbon content and surface area obtained for walnut shells (WS) samples are found as $\sim 18.4 \mathrm{MJ} \mathrm{kg}^{-1}$, $>80 \%$ and $58 \mathrm{~m}^{2} / \mathrm{g}$, respectively. Improvement in $\mathrm{HHV}$ and decrease of $\mathrm{O} / \mathrm{C}$ and $\mathrm{H} / \mathrm{C}$ ratios lead the bio-char samples to fall into the category of coal and confirmed their hydrophobic, carbonized and aromatized nature. From the Fourier transform infra-red spectroscopy (FTIR), it is observed that there is alteration in functional groups with increase in temperature, and illustrated higher aromaticity. This showed that bio-chars have high potential to be used as solid fuel either for direct combustion or for thermal conversion processes in boilers, kilns and furnace. Further, from surface area and $\mathrm{pH}$ analysis of bio-chars, it is found that WS bio-chars have similar characteristics of adsorbents used for water purifications, retention of essential elements in soil and carbon sequestration.
\end{abstract}

Keywords: walnut shells; pyrolysis; higher heating values; bio-char; surface area

\section{Introduction}

Continuous environmental issues, ascending prices of petroleum, energy crisis, exhaustion of fossil fuels, increasing application and need for energy are the serious motivations, due to which there is much insistence on substitute sustainable energy sources. Environmental friendliness, sustainability and biodegradability are the important characters which have made the biomass a primary candidate for the generation of bio-energy. The conversion technologies are the possible options to explore the economic potential of bio-resources. Biofuels and bio-chemicals are formed through thermo-chemical conversion, which includes pyrolysis, gasification, liquefaction and combustion [1]. Pyrolysis is the most striking process for converting biomass into bio-fuels [2]. Volatiles and semi-volatiles are discharged from the 
feedstock residues during pyrolysis of biomass and yields gases, bio-oil and chars. Further, bio-char may be formed with re-condensing vapors into the bio-char material depending on the residence time of vapor, which increases the bio-char products $[3,4]$.

Bio-char is the solid yield of pyrolysis and has different properties in comparison to the corresponding feedstock's, and can deliver considerable and sustainable diversity in securing an upcoming resource of green energy [5]. It has got several commercial applications, such as fuel production [6,7], energy storage [8], soil improvement [9], soil conditioner [4,10] animal farming, building sector, drinking and wastewater treatments, biogas production, industrial materials (plastics, carbon fibers), exhaust filters, energy production (substitute for lignite, pellets), electronics semiconductors, batteries), paints and coloring (industrial paints, food colorants), cosmetics (therapeutic bath additives, skin-cream, soaps), medicines (detoxification, carrier for active pharmaceutical ingredients), etc. [10-14] as illustrated in Figure 1. Further it can be upgraded by using appropriate methods [15], to form activated bio-char and value-added yields. Due to these applications, bi-ochar may be used as soil amendment and solid fuel due its high porosity, specific surface area and heating value near to coal. In Taiwan, bio-char is largely used for soil alteration as a result of its high-water absorption and surface area and acting as an activated carbon [16].

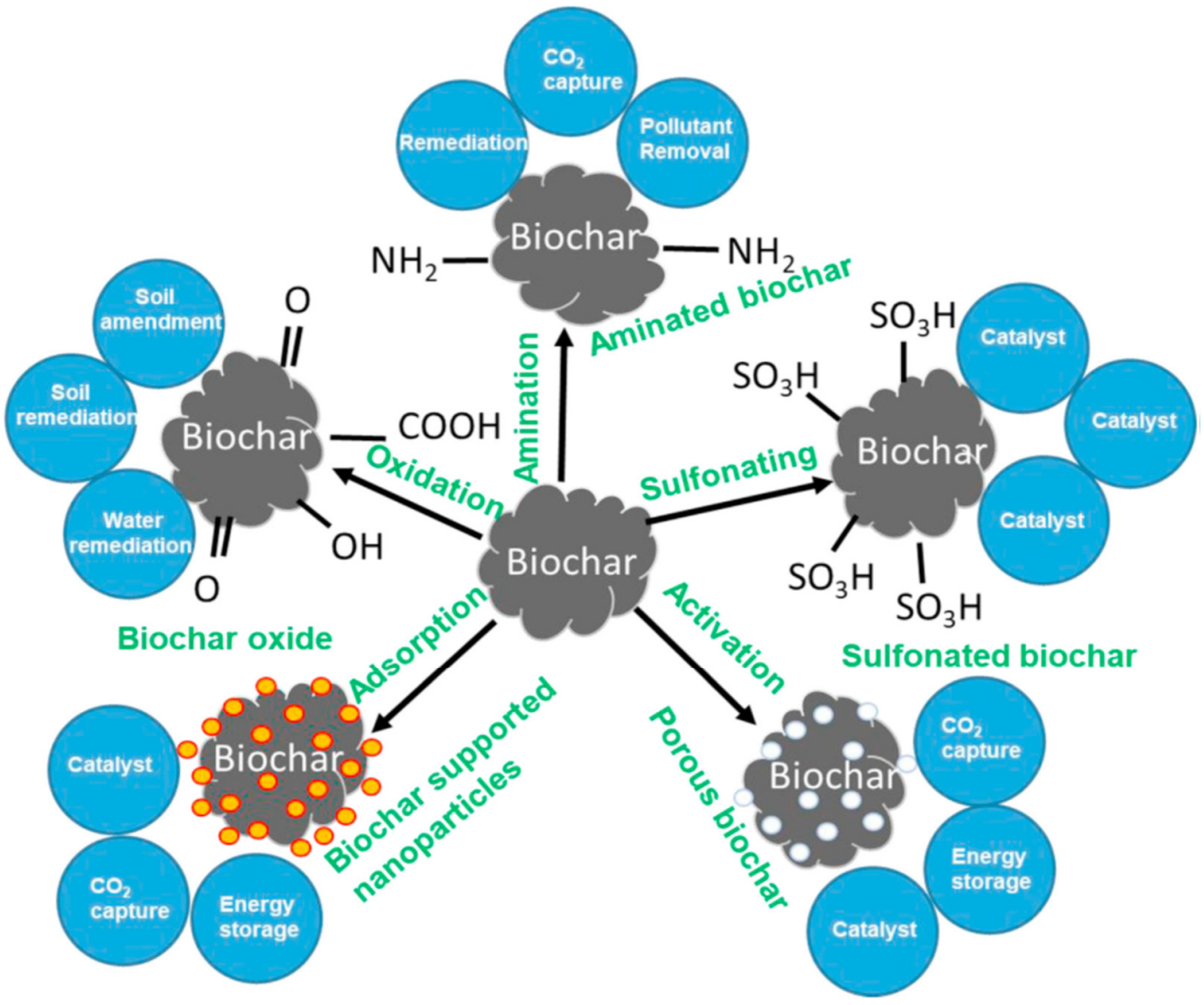

Figure 1. Bio-char potential applications of different sectors.

The origin of biomass source is an important parameter, which influences the characteristics of bio-char yield. Diversified potential biomass residues exist for bio-char formation including municipal wastes, animal manures, forestry and agricultural residues and another growing biomass. A large number of characters should be considered, however, when determining biomass feedstock suitability, like the sustainability requirements, possible toxicity of the bio-char, desired bio-char characteristics and end use [17]. The characteristics of the bio-char are affected by number of variables, such as pyrolysis temperature (maximum or minimum), feedstock size, retention time at the maximum temperature and the pyrolysis atmosphere $[4,17,18]$. A number of studied reported that the surface area of bio-char is higher as compared to their respective biomass [19] which makes bio-char is a 
suitable candidate to be either used as an adsorbent or as bio-fuel. Additionally, bio-char obtained from biomass is rich in minerals, therefore it can also be used to improve soil conditions [4,17]. Walnut shell bio-char may be a future and eco-friendly candidate for solid biofuel. Due to its high heating value and may replace the coal fuels $\left(30 \mathrm{MJ} \mathrm{kg}{ }^{-1}\right)$ in future. Jiang et al. [20], obtained chestnut bio-char by pyrolysis and the preparation were done by catalytic pre-oxidation with urea and sulfuric acid. The high heating ( $\left.35.48 \mathrm{MJ} \mathrm{kg}{ }^{-1}\right)$ value was recorded by this method.

Thermochemical conversion technologies such as pyrolysis are dominant to avert secondary pollution and beginning circular bioeconomy [21]. Environmentally sustainable and economically feasible technologies must be engaged to execute industrial-scale pyrolysis for manufacture of biochar, thus ease to commercialization and possible applications of biochar-based yields [4]. Pyrolysis of lignocellulosic biomass residues is an energy strategy and carbon-negative, needs profound investigation activities internationally [22] in the field of renewable energy substitutions [23], environmental pollution control [24], climate mitigation [25], sustainable towards food security and agriculture [26].

Ghodake et al. [27] reported an extensive work on pyrolysis mechanism and physicochemical properties of biochar. They discussed various aspects of in-management of biomass feedstocks supply chain, biomass feedstock composition and pyrolysis products. They discussed the possibility of a sustainable way of bio-char production and also how this could be a great material for soil amendment, agricultural and to achieve circular bioeconomy. Further, Lin et al. [28] have studied the torrefaction of fruit peel waste to yield environmentally friendly biofuel. In their work, it was reported that they used Ananas comosus peel and Annona squamosa peel samples to produce bio-char as a renewable energy source. Interestingly, it was found that the higher heating value of both bio-char was increased to $19.1-27.7 \mathrm{MJ} / \mathrm{kg}$ after torrefaction. Additionally, they reported a high energy return on investment for renewable energy. Moreover, it was emphasized that the application of bio-char for partial coal substitution can reduce $\mathrm{CO}_{2}$ emissions by 83.7-94.3\%. Further, Romanowska-Duda et al. [29] discussed the promotive effect of Cyanobacteria and Chlorella sp. foliar biofertilization to produce feedstock production, solid biofuel and biochar. It was reported that triple foliar plant spraying with non-sonicated monocultures of Cyanobacteria and Chlorella sp. exhibited a considerably progressive impact on metabolic activity and development of plants. Bio-char can be produced in all scales from individual, domestic as well as the industrial levels and is most prominent and leading industry at various socioeconomic settings. The opportunity of multi-functionality structures and sustainable bio-char production practices creates an increasing demand in the fields of cutting-edge materials, soil amendment, environmental protection, agricultural sustainability and to achieve mitigation of climate variation and circular bio-economy. There is a necessity to understand the prediction of organic molecules, bioavailability, toxicity, concentration, surface functions, surface radicals, mobility and environmental fates about bio-char structures. The correlation between the structure, applications and mechanisms of bio-char is progressively developing to enhance their agronomic uses, to achieve precisely designed bio-char with a zero-waste dream [27-29].

In addition, circular bioeconomy focuses on the sustainable and resource-saving value of biomass in a broad and multi-generational production chain. Additionally utilizing residues and waste to optimize the value cascade of biomass in production. Recently, D'Adamo, Morone and Huisingh [30] discussed a sustainable shift towards bioenergy. In this work they reiterated that bioenergy should be included in the bioeconomy sector. In that case, it would also include the agriculture and forestry and new manufacturing sectors. Currently, several types of agrochemical and biochemical processes are adapted to convert lignocellulosic residues into value-added yields. The microbial delignification joined with hydrolysis to increase biofuel yields such as methane [31], butanol [32], ethanol [33], hydrogen production [34] and fuel briquettes [35]. None of the literature reported the comparative study of four different types of walnut shells. In addition to this, we have carried out research work on the biomass agriculture residues available in 
the State of Jammu and Kashmir, India, which has been again not studied earlier for this particular geographical area.

In the present study, walnut shells are considered as biomass residue for the production of bio-char. Walnut is cultivated mainly in Asian, European and American regions and is one of the important agricultural products for dry fruit industry. In the last decade, the production of walnut has increased by $\sim 25 \%$ [36]. Walnut consists of oily material kernel $(60 \%)$ and a hard covering shell (40\%) [37]. The walnut shells, lignocellulosic biomass, have no utilization except being directly used for combustion in furnace, otherwise it is dumped in open areas. This study investigates the physio- and thermochemical characterization of bio-chars obtained from hard-shelled walnut (HSW), medium-shelled walnut (MSW), thin-shelled walnut (TSW) and paper-shelled walnut (PSW). HHV and molar ratios of hydrogen to carbon $(\mathrm{H} / \mathrm{C})$ and oxygen to carbon $(\mathrm{O} / \mathrm{C})$ are determined. The $\mathrm{pH}$ values and surface area of different bio-chars are determined to propose their specific applications. Three different heating rates are used for TG analysis. Furthermore, bio-chars are also investigated by scanning electron microscopy, X-ray diffraction and Fourier transform infrared spectrometry to understand the product profile of bio-char samples obtained from different walnut shell samples.

\section{Materials and Methods}

\subsection{Sample Collection and Preparation}

Walnut samples of HSW, MSW, TSW and PSW were collected from the walnut business unit Jammu and Kashmir, India, and sundried for three days at a temperature of $25{ }^{\circ} \mathrm{C}$ with less than $47 \%$ humidity. Thereon, it was crushed by high speed ball mill and passed through screens in order to obtain particle sizes of 2.5-3, 1.5-2.5 and 0.5-1.5 $\mathrm{mm}$. The sample biomass residues (Figure 2) was packed in an airtight PVC jar and stored in desiccators for further experiments.

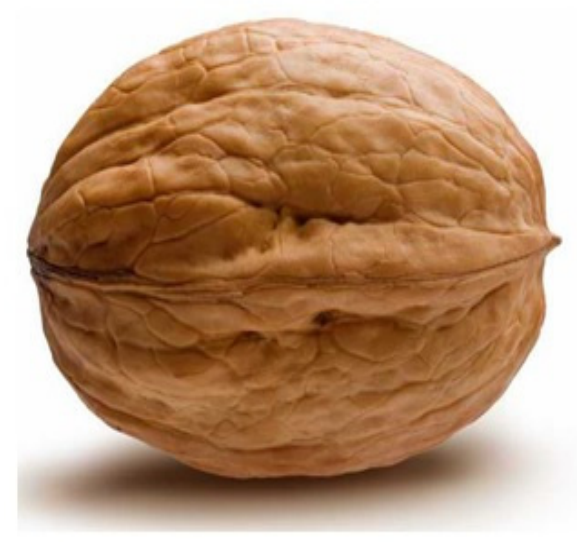

(a)

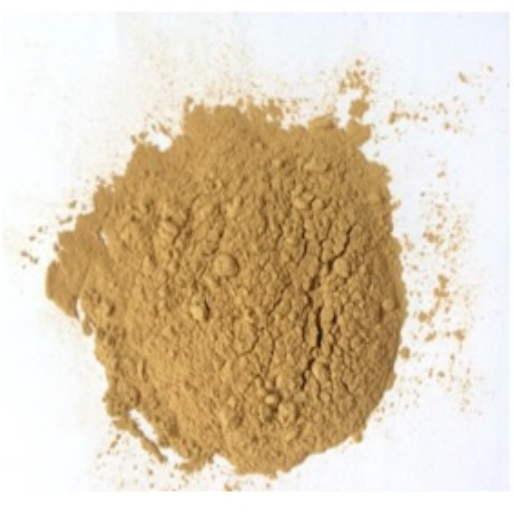

(b)

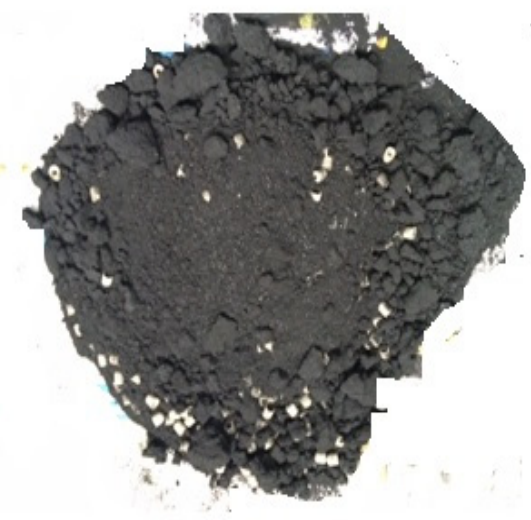

(c)

Figure 2. (a) The original shape of walnut (b) shell residues and (c) their respective bio-chars.

\subsection{Pyrolysis Setup: Pyrolysis of Biomass in a Fixed-Bed Reactor}

Pyrolysis was carried out in a fixed-bed reactor. The internal diameter and length of the reactor were 122.26 and $1200 \mathrm{~mm}$, respectively. The design pressure and temperature were 12 bars and $950{ }^{\circ} \mathrm{C}$, respectively. It was surrounded by an electric furnace with P\&ID controller to supply power for heating. Ni-Cr thermocouple was used to sense the temperature inside the reactor. A batch of $300 \mathrm{~g}$ of the individual feedstock was charged for pyrolysis by increasing the temperature from ambient to $375,450,550,650$ and $750{ }^{\circ} \mathrm{C}$, respectively, at a heating rate of 10,20 and $50{ }^{\circ} \mathrm{C} / \mathrm{min}^{-1}$. Nitrogen at a flow rate of 50,100 and $150 \mathrm{~cm}^{3} / \mathrm{min}$ was used to keep the environment inert and oxygen-free, and also to carry over the condensable vapors produced during pyrolysis. These vapors were collected in a condensers I and II to collect oil and scrubbing tank to collect gas. The reaction was 
performed for $35 \mathrm{~min}$, or till no further release of gas was observed. Further, the bio-char was collected after cooling down the pyrolizer to room temperature. The bio-char samples were stored in airtight PVC containers for further analysis.

\subsection{Material Analysis}

The proximate analysis of the bio-char samples was carried out as per ASTM standard procedures: E871-82 (2013), D1102-84 (2013) and E872-82(2013) for ash and volatile matter contents, respectively. Ash and volatile matters were determined at a temperature of $580{ }^{\circ} \mathrm{C}$ for $30 \mathrm{~min}$ and at a temperature of $950{ }^{\circ} \mathrm{C}$ for $7 \mathrm{~min}$, respectively. Fixed carbon was calculated by subtracting the summation of the percentages of moisture, ash and volatile matters from 100. All percentages were on the same moisture reference basis (ASTM E871-82, 2013; (ASTM D1102-84, 2013; ASTM E872-82, 2013) [38-40].

Energy yield and densification of the bio-char yield produced at $375^{\circ} \mathrm{C}$ were also calculated, according to the method proposed by Chowdhury et al. (2017) [41]. The energy densification was obtained by high heating value (HHV) of bio-chars divided by the HHV of biomass residues and the energy yield was calculated as the energy densification multiplied by the bio-char yield [42]. Ultimate analysis was achieved by using a CHNS elemental analyzer (Euro EA3000, Euro vector, Pavia, Italy) as per ASTM procedure D5373-08(ASTM D5373-08, 2008) [43]. Higher heating values of the bio-char were determined by bomb calorimeter (CC01/M3; Toshniwal, New Delhi, India) using ASTM procedure D2015-85. $1.0 \mathrm{~g}$ bio-char samples was implanted in a calorimeter, and inflamed in the presence of oxygen. The heat of combustion was recorded for the calculation of HHV of bio-char samples (ASTM D-85, 2015) [44].

Surface area, pore volume and average pore size measurements of bio-char samples, obtained from different walnut shell residues, were investigated by nitrogen $\left(\mathrm{N}_{2}\right)$ adsorption/desorption isotherms at $77 \mathrm{~K}$ using Micromeritics ASAP 2060 V3.05 H Surface Area Analyzer (Brunauer-Emmett-Teller). About $3 \mathrm{mg}$ of bio-char samples was degassed for $6 \mathrm{~h}$ at $200{ }^{\circ} \mathrm{C}$ under vacuum. Pore volume and average pore size were observed by using Barrett-Joyner-Halenda (BJH) and surface area with BET method.

The $\mathrm{pH}$ bio-char samples was measured using the following procedure: A total of $20 \mathrm{~mL}$ of deionized water was mixed with $0.5 \mathrm{~g}$ of bio-char with the help of magnetic stirrer, for $24 \mathrm{~h}$ at $100{ }^{\circ} \mathrm{C}$ at $150 \mathrm{rpm}$, in order to get homogeneous solution [43]. The suspension is filtered and equilibrium was reached after one hour. $\mathrm{pH}$ of the filtered sample was measured by using Orion pH meter (Thermo Scientific, Cambridge, MA, USA) for bio-char samples.

TGA was carried out by the thermogravimetric analyzer (SII 6300 Exstar; Hitachi, Tokyo, Japan). Runs were accomplished non-isothermally at three different heating rates $\left(10,20\right.$ and $\left.50{ }^{\circ} \mathrm{C} / \mathrm{min}\right)$. Nitrogen was used as a carrier gas, at a flow rate of $100 \mathrm{~mL} \mathrm{~min}^{-1}$. Bio-char samples were placed on an open platinum sample pans during the TG analysis. A bio-mass sample of $10 \pm 0.26 \mathrm{mg}$ was used in the experiments. The changes in mass of samples with temperature were recorded for further analysis.

The morphology of the bio-char samples of different walnut shell residues was determined using a SEM (S 3600; Hitachi, Japan) analysis. Images were taken at $15 \mathrm{kV}$ with $10,000 \times$ magnification. The X-ray source was tungsten filament dazed with lanthanum hexaboride $\left(\mathrm{LaB}_{6}\right)$, which was equipped with a secondary electron detector (i.e., Evehart-Thornley detector (ETD)). The biomass samples were circulated on a carbon coated adhesive pursued by vapor-deposition with gold before investigation. XRD was performed on the bio-char samples using the diffractometer (D8-Advance; Bruker, MA, USA) (fitted with a Lynx eye high-speed strip detector) with $\mathrm{Cu}$ Ka radiation $(\lambda=0.15432 \mathrm{~nm})$. One gram of each bio-char samples was granulated for powder diffraction using X-Ray source with $2.2 \mathrm{~kW} \mathrm{Cu}$ anode $(40 \mathrm{kV}, 40 \mathrm{~mA})$ under angular range $2 \theta(5-1200)$. For collection of data from $0.5^{\circ}$ to $5^{\circ}$ of $2 \theta$ a regular mode was employed at a scanning speed of $2^{\circ} / \mathrm{min}$.

FTIR spectroscopy of different bio-char samples was carried out using a Nicolet 6700 , Thermo scientific USA instrument. FTIR analysis the sample powder diluted in $1 \%$ potassium bromide $(\mathrm{KBr})$. The FTIR spectrum in the range of $500-4000 \mathrm{~cm}^{-1}$ was measured with a resolution of $4 \mathrm{~cm}^{-1}$. 
The bio-char showed maximum yields at $375^{\circ} \mathrm{C}$ and the characteristics of biochar, like proximate analysis, ultimate analysis, $\mathrm{HHV}$ and molar ratios of hydrogen to carbon $(\mathrm{H} / \mathrm{C})$ and oxygen to carbon $(\mathrm{O} / \mathrm{C})$, were determined at $375^{\circ} \mathrm{C}$. The $\mathrm{pH}$ values, surface area, TG analysis, scanning electron microscopy (SEM), X-ray diffraction (XRD) and Fourier transform infrared (FTIR) spectrometry were analyzed in the same temperature.

\section{Results and Discussion}

\subsection{Proximate and Ultimate Analysis}

The results obtained from proximate (on dry ash free (daf) basis) and ultimate analysis, and the corresponding $\mathrm{H} / \mathrm{C}, \mathrm{O} / \mathrm{C}$ and $\mathrm{HHV}$ data, are shown in Tables 1 and 2. For the purpose of comparison, the earlier work reported on bio-chars obtained from different biomass residues, such as almond shell [45], palm shell [17], wheat straw [46] and also for coal [47], were included in Tables 1 and 2. For a bio-char sample to be considered as bio-fuel, moisture content is an important component. The higher moisture content lowers the heating value and hence affects physical properties and the quality of the yields, which in turns affects the behavior of fuel properties. The results show that moisture contents in the bio-chars are in the range of $0.2-0.8 \%$, which are comparable with wheat straw [46] but much lower than the moisture contents reported for coconut shell bio-chars (7.1 wt\%) [17], lignite $(34 \mathrm{wt} \%)$ and bituminous coals (11 $\mathrm{wt} \%)$ [47].

Fixed carbon (FC) and volatile matters (VM) contents of the bio-char are significant depending on the type of its utilization as an energy source. For bio-chars used in the present work, the VM contents fall in the range from 8.7-14.4\%, which are comparable with palm shell [17] but higher than coconut shell [17] and wheat straw bio-chars [46]. However, the values are much lower than lignite (29\%) and bituminous coals (35\%) [47]. the highest and lowest VMs were observed in PSW and HSW bio-chars, respectively. The reduction of volatile matters was due to conversion of volatile matter into pyrolysis products.

FC contents varied from $78.4-85.6 \%$, which are comparable with the values reported for almond shell [45] and palm shell chars [17]. However, they were found much higher than bituminous and lignite coals. The highest carbon content present in HSW bio-char $(85.6 \%)$ implies that hard-shelled bio-char yield would be the largest among all types of bio-char samples.

Table 1. Proximate analysis, high heating values, energy density and energy yield of bio-char obtained at particle size of $+1.5-2.5 \mathrm{~mm}$, heating rate $20^{\circ} \mathrm{C} / \mathrm{min}$ at $375^{\circ} \mathrm{C}$ and comparison with other bio-chars.

\begin{tabular}{|c|c|c|c|c|c|c|c|c|}
\hline \multirow[b]{2}{*}{ Types of Bio-Char } & \multicolumn{8}{|c|}{ Proximate Analysis (wt $\%$ daf) } \\
\hline & $\mathbf{M}$ & VM & $\mathbf{A}$ & FC & $\begin{array}{c}\text { HHV } \\
(\mathrm{Mj} / \mathrm{Kg})\end{array}$ & ED & EY & References \\
\hline PSW & 0.8 & 14.4 & 5.5 & 78.5 & 14.8 & 1.08 & 72.6 & \multirow{4}{*}{ Present work } \\
\hline TSW & 0.6 & 12.1 & 4.4 & 78.4 & 15.2 & 1.11 & 72.6 & \\
\hline MSW & 0.3 & 11.7 & 3.2 & 84.2 & 16.6 & 1.15 & 69.7 & \\
\hline HSW & 0.2 & 8.7 & 2.02 & 85.6 & 18.4 & 1.26 & 71.9 & \\
\hline Almond shells char & - & 21.2 & 1.9 & 76.9 & 28.2 & - & - & {$[45]$} \\
\hline Palm shell char & 2.2 & 11.5 & 6.7 & 88.5 & 33.6 & - & - & \multirow{2}{*}{ [17] } \\
\hline Coconut shell & 7.1 & 8.1 & 4.1 & 91.9 & 33.7 & - & - & \\
\hline $\begin{array}{l}\text { Wheat straw bio-char } \\
\text { (WSB) }\end{array}$ & $0.6 \pm 0.01$ & 7.3 & $8.2 \pm 0.2$ & 83.9 & $22.0 \pm 0.7$ & - & - & [46] \\
\hline Coal (lignite) & 34 & 43.93 & 9 & 46.96 & $9.3-19.3 *$ & - & - & \multirow{2}{*}[47]{} \\
\hline Coal (bituminous) & 11 & 39.93 & 10.11 & 50.56 & $27.9-34.89 * *$ & - & - & \\
\hline
\end{tabular}


Table 2. Elemental analysis and $\mathrm{H} / \mathrm{C}$ and $\mathrm{O} / \mathrm{C}$ values of bio-chars obtained at particle size of $+1.5-2.5 \mathrm{~mm}$, heating rate $20{ }^{\circ} \mathrm{C} / \mathrm{min}$ at $375^{\circ} \mathrm{C}$ and comparison with other bio-chars and coals.

\begin{tabular}{|c|c|c|c|c|c|c|c|}
\hline \multirow{2}{*}{ Type of Bio-Chars } & \multicolumn{7}{|c|}{ Ultimate Analysis (wt \%) } \\
\hline & $\mathrm{C}$ & $\mathbf{H}$ & $\mathbf{N}$ & $\mathbf{O}$ & $\mathrm{H} / \mathrm{C}$ & $\mathrm{O} / \mathrm{C}$ & References \\
\hline PSW & 73.4 & 3.0 & 0.8 & 22.7 & 0.49 & 0.3 & \multirow{4}{*}{ Present work } \\
\hline TSW & 76.6 & 2.4 & 0.8 & 15.2 & 0.31 & 0.19 & \\
\hline MSW & 81.8 & 3.0 & 0.6 & 19.6 & 0.36 & 0.23 & \\
\hline HSW & 82.7 & 2.38 & 0.8 & 14.0 & 0.28 & 0.17 & \\
\hline Walnut shell & 55.3 & 0.89 & 0.47 & 1.6 & & & [35] \\
\hline Apricot Kernel shell char & 72.72 & 3.17 & 1.27 & 19.84 & 0.50 & - & [19] \\
\hline Barley straw & 74.83 & 3.51 & 0.10 & 8.46 & & & [48] \\
\hline Wheat straw bio-char (WSB) & 64.8 & 3.1 & 0.8 & 23.0 & 0.6 & 0.3 & [46] \\
\hline Coal (lignite) & 56.4 & 4.2 & 1.6 & 18.4 & - & - & \multirow{2}{*}{ [47] } \\
\hline Coal (bituminous) & 73.1 & 5.5 & 1.4 & 8.7 & - & - & \\
\hline
\end{tabular}

The chemical composition of the ash can create significant operational problems in a thermo-chemical conversion process, such as combustion processes due to formation of slag from ash at elevated temperatures. For the various bio-chars under study, the ash contents varied from $2.0-5.5 \%$. Where, HSW contains the lowest value, $2.0 \%$, and PSW bio-char exhibits the highest value, $5.5 \%$. The ash contents of the walnut shell bio-chars are well within the range as reported for palm shell, wheat straw, coconut shell, almond shell bio-chars and coals (Table 1).

The ultimate analysis revealed that the carbon, hydrogen, nitrogen and oxygen contents are almost comparable with each other. The ranges may also be tallied with the values reported in the literature for apricot kernel shell [19] and wheat straw and other agricultural bio-chars [48-50]. However, some large variations have been observed in hydrogen and oxygen for walnut shell [50], and nitrogen and oxygen contents in barley straw [48]. They were highly carbonaceous, with carbon contents ranging from $73.4 \%$ to $82.7 \%$, and much less nitrogen content $(n<1 \%)$, which produces a lesser amount of $\mathrm{NO}_{\mathrm{X}}$ during pyrolysis.

The energy densification and yield vary from 1.08 to 1.26 and from $69.7 \%$ to $72.6 \%$, respectively. These values are almost comparable with each other for the bio-chars under investigation. However, the energy densification values are lower and yields are higher than the values reported by Rather et al. (2017) [51] for weeds bio-char.

$\mathrm{H} / \mathrm{C}$ and $\mathrm{O} / \mathrm{C}$ data plotted on the van Krevelen diagram (Figure 3) show that the energy quality of the bio-char is improved in comparison to the feedstock, and the bio-char may be compared with lignite coal and other walnut shell and apricot Kernel shell $[19,47,50]$ bio-chars. The reduction in $\mathrm{O} / \mathrm{C}$ and $\mathrm{H} / \mathrm{C}$ ratios is due to the loss of oxygen and hydrogen during pyrolysis and may be attributed to decarboxylation and demethylation, respectively [50].

From Tables 1 and 2 it can be concluded that the fuel qualities of the different bio-char samples are improved tremendously, as compared to their respective biomass residues. On comparison of bio-char samples with other biomass residues, it was observed that volatile matters, oxygen and ash contents decreased and fixed carbon and carbon content increased. This shows that bio-char samples have high potential to be used as a solid fuel either for direct combustion or for thermal conversion processes.

HHVs vary from 14.8 to $18.4 \mathrm{MJ} / \mathrm{kg}$. The values are comparable with the results for lignite coal as reported by McKendry (2002) [47]. The results obtained in the present investigation show that the fuel qualities in terms of energy value and fixed carbon contents of the bio-chars are improved in comparison to the respective biomass residues. Thus, the bio-chars have the potential to be used as solid fuels. 


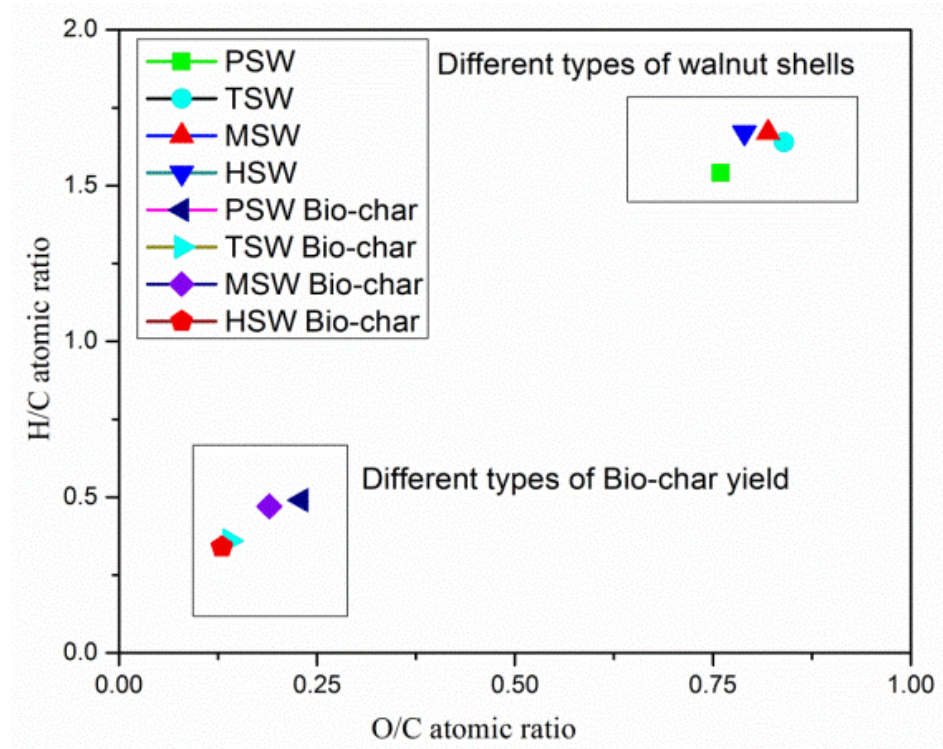

Figure 3. Van Krevelen diagram of different types of walnut shells and their respective bio-char yields.

\subsection{TGA Analysis of Bio-Char}

The results of TGA carried out in an oxidizing atmosphere at 10,20 , and $50^{\circ} \mathrm{C} / \mathrm{min}$ heating rates are revealed in Figure 4. The weight loss range can be classified into the three divisions. Every new slope indicates the beginning of a new stage. In the first division, about $\approx 2.5-7 \%$ mass loss was observed between the temperatures from 29 to $160^{\circ} \mathrm{C}$ for all heating rates and for all types of bio-chars. In the first stage, the maximum mass loss seems to occur in TSW $(7 \%)$ at $20^{\circ} \mathrm{C} / \mathrm{min}$ and the lowest in HSW bio-char $(2.5 \%)$ at a heating rate of $50{ }^{\circ} \mathrm{C} / \mathrm{min}$ (Figure $4 \mathrm{~b}, \mathrm{~d}$ ). The mass loss is due to the removal of moisture and sorbent water bounded by surface tension. The second zone starts at $330^{\circ} \mathrm{C}$ and continued up to $475{ }^{\circ} \mathrm{C}$ where the mass loss from $75-81 \%$ at $10^{\circ} \mathrm{C} / \mathrm{min}, 78-89 \%$ at $20^{\circ} \mathrm{C} / \mathrm{min}$, and $81-90 \%$ at $50{ }^{\circ} \mathrm{C} / \mathrm{min}$ are recorded for all bio-chars. A huge weight loss of $90 \%$ for HSW at a heating rate of $50{ }^{\circ} \mathrm{C} / \mathrm{min}$ and average weight loss of $82.5 \%$ were observed for rest of the bio-chars, see Figure $4 \mathrm{~d}$. In this zone the mass loss is due to the existence of cellulose and lignin contents which undergo a oxidation/devolatization reaction. The third zone starts at $475{ }^{\circ} \mathrm{C}$ and continues with almost negligible loss of mass. The decomposition of lignin takes place very slowly in the third zone as a result almost straight line is observed. The behavior of TGA analysis was found in agreement with the outcomes described in the literature [52-57].

The above statement is also endorsed by the research carried out many other researchers [58-60] with respect to the decomposition of cellulose, hemi-cellulose, and lignin within the given temperature ranges. The thermogravimetric analysis of various bio-char samples in an oxidizing atmosphere suggested that produced bio-char can be used as alternative solid fuel for various processes.

From the TG curves, a decomposition performance may be illuminated by the specific constituents of bio-chars, whereby the cellulose, hemi-cellulose and lignin are the main components and extractives are the minor components. It was also noticed that the decomposition of cellulose, hemi-cellulose and lignin was accomplished at temperature intervals of $310-400,210-325$, and $160-900{ }^{\circ} \mathrm{C}$, respectively, which is comparable to other bio-chars [56-60]. Therefore, it can be concluded that the major and minor reactions, as detected, in the active pyrolysis zone may be credited to cellulose and hemi-cellulose decomposition. The final zone revealed much less mass loss due to slow degradation of lignin at 510 to $800{ }^{\circ} \mathrm{C}$ to produce bio-char as residue [61,62]. Similar observations have also been made by other researchers [61-63]. It was also observed that, at low heating rate, the pyrolysis above $550{ }^{\circ} \mathrm{C}$ was almost negligible. 




(a)

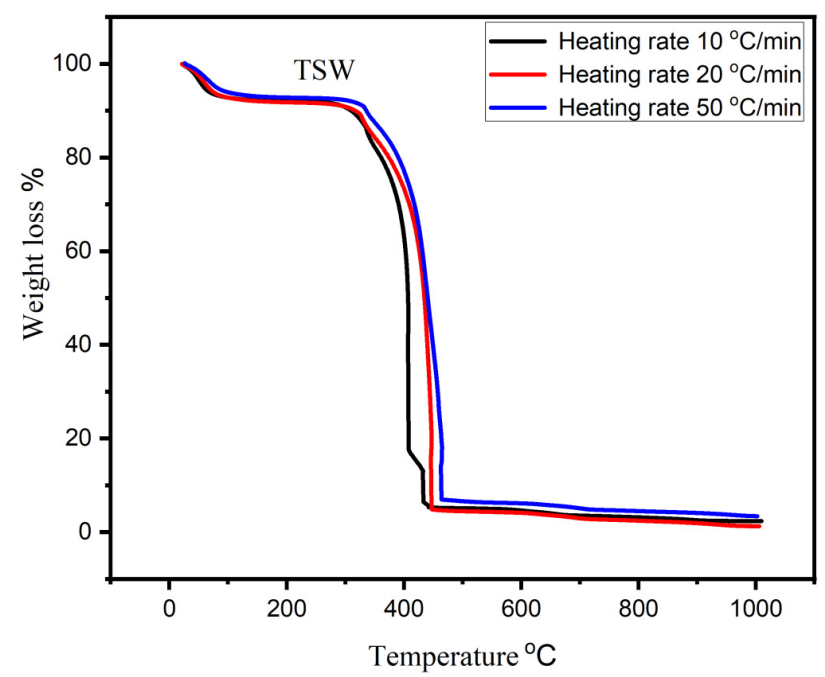

(b)

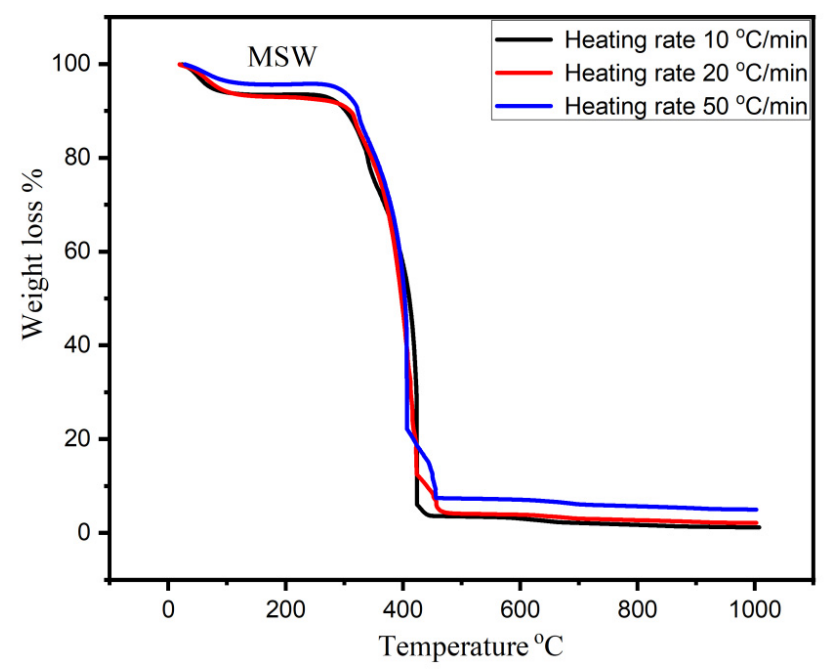

(c) 


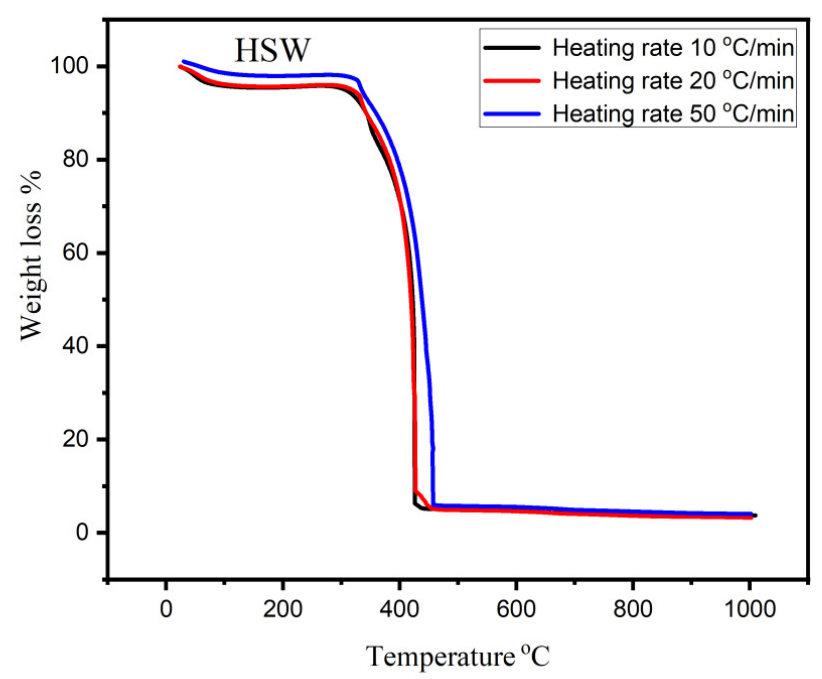

(d)

Figure 4. (a-b) TGA profiles of (a) PSW, (b) TSW, (c) MSW and (d) HSW bio-char in an oxidizing atmosphere at 10,2 , and $50{ }^{\circ} \mathrm{C} / \mathrm{min}$ heating ranges.

\subsection{SEM and XRD Analysis of Bio-Chars}

The surface morphology of bio-chars, collected from SEM analysis, is exhibited in Figure 5. It is evident that PSW (a) shows porous cracks and HSW (d) shows the agglomerated rocky-like structure. However, TSW (b) and MSW (c) show planner sheet-like structures. The structures have rough textures and are heterogeneous in nature. The results are similar to those found by Guerrero et al. (2008) [64], where they mentioned melting followed by devolatization and finally vesicle formation responsible for the formation of such structures [64,65]. As temperature gets increased with high heating rate, there is release of various volatile components. Devolatilization results in morphological changes of bio-char, followed by the formation of high pore surface structure of bio-char samples [54].

The XRD patterns of the bio-chars at a temperature of $375{ }^{\circ} \mathrm{C}$ are shown in Figure 6. The peaks are in the range of 5-900 on the base line of the diffractograms. The peaks at $14^{\circ}$ (d-space $\left.5.96 \AA\right), 15^{\circ}(\mathrm{d}$-space $\sim 5.7 \AA), 16^{\circ}(\mathrm{d}$-space $5.3 \AA), 22^{\circ}(\mathrm{d}$-space $\sim .0 \AA), 26^{\circ}$ (d-spa1ce $3.34 \AA$ ) and $35^{\circ}$ (d-space $2.5 \AA$ ) were assigned to cellulose and hemi-cellulose,

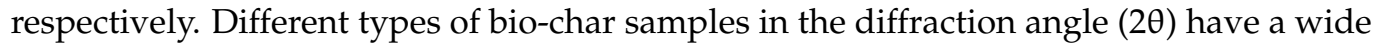
halo in the $2 \theta$ range from 6 to $20^{\circ}$, showed that chain contains large number of carbons containing components substances. The band at $2 \theta=22^{\circ}$ showed disordered structure, which occurred due to presence of aliphatic and distorted arrangement of carbon chain. Broad peak at $2 \theta \approx 26^{\circ}$ of bio-char indicated presence of silica in the X-ray diffractogram. The peak at 15 and $16^{\circ}$ were derived from cellulose constituent. Bio-char samples showed narrow and sharp bands over the examined $2 \theta$, due to the presence of inorganic constituents in the carbon chain. The XRD graphs confirmed the aromatic and crystallinity nature of the bio-chars, which is in agreement with other bio-chars [65-67]. 


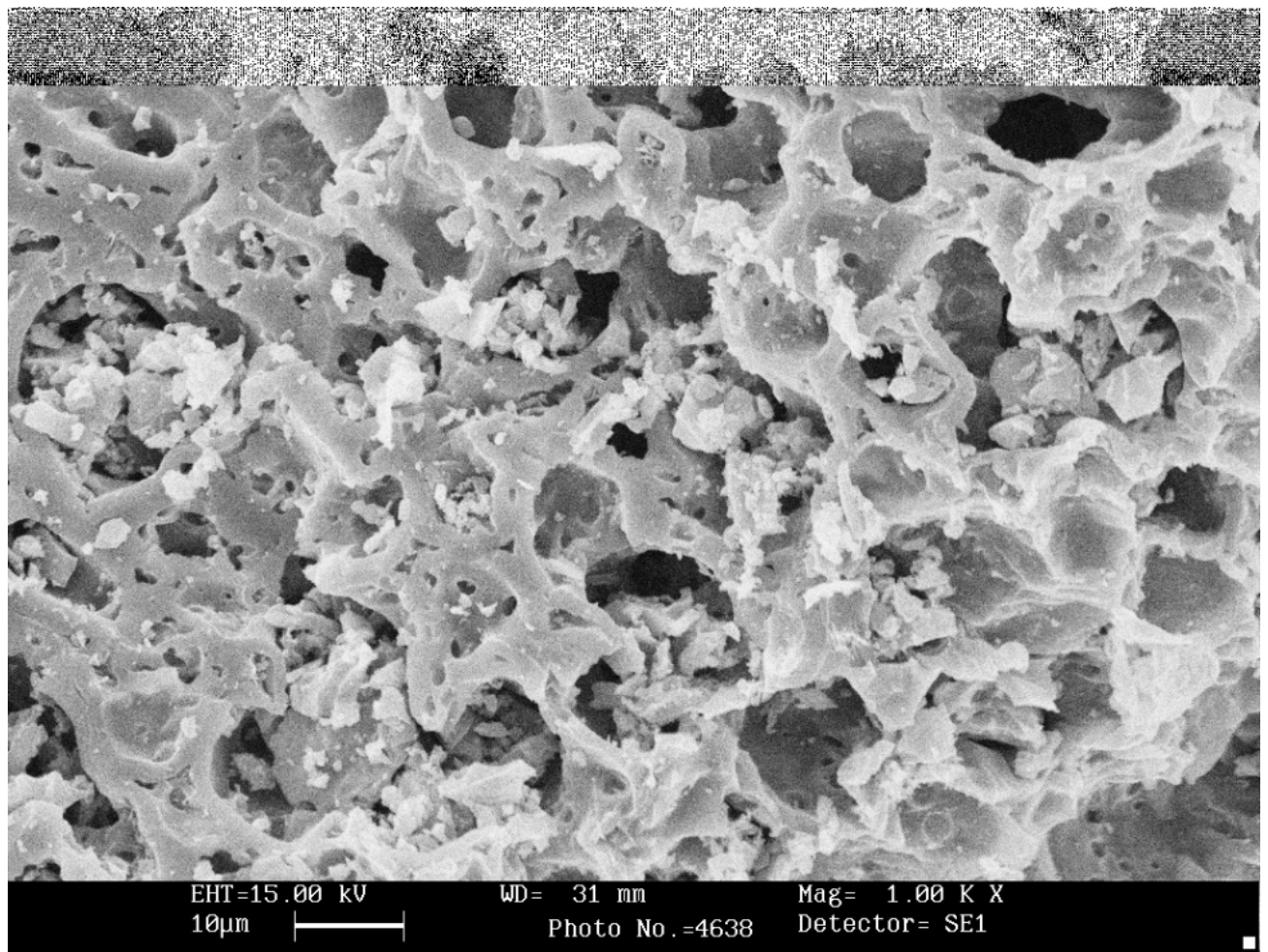

(a)

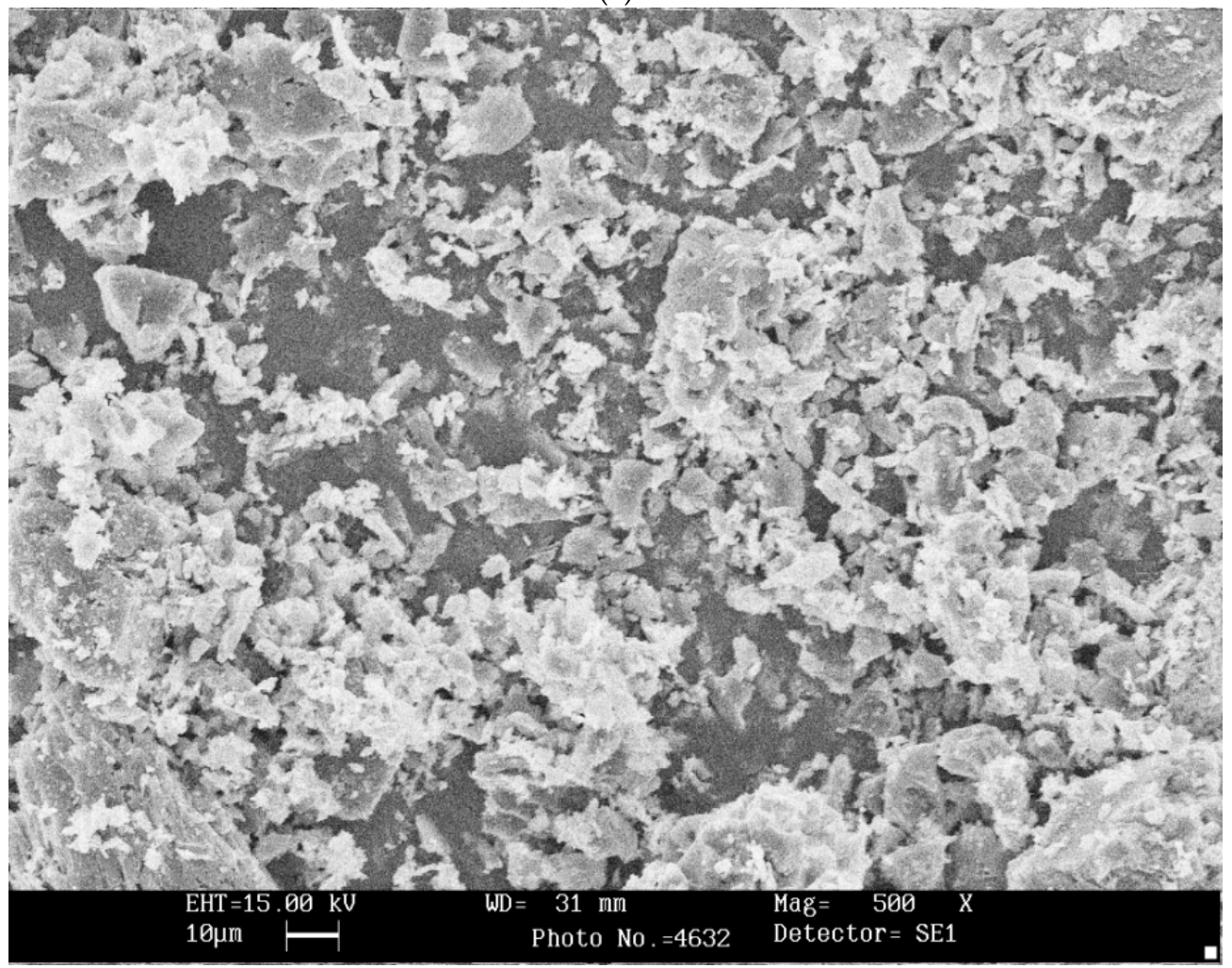

(b) 


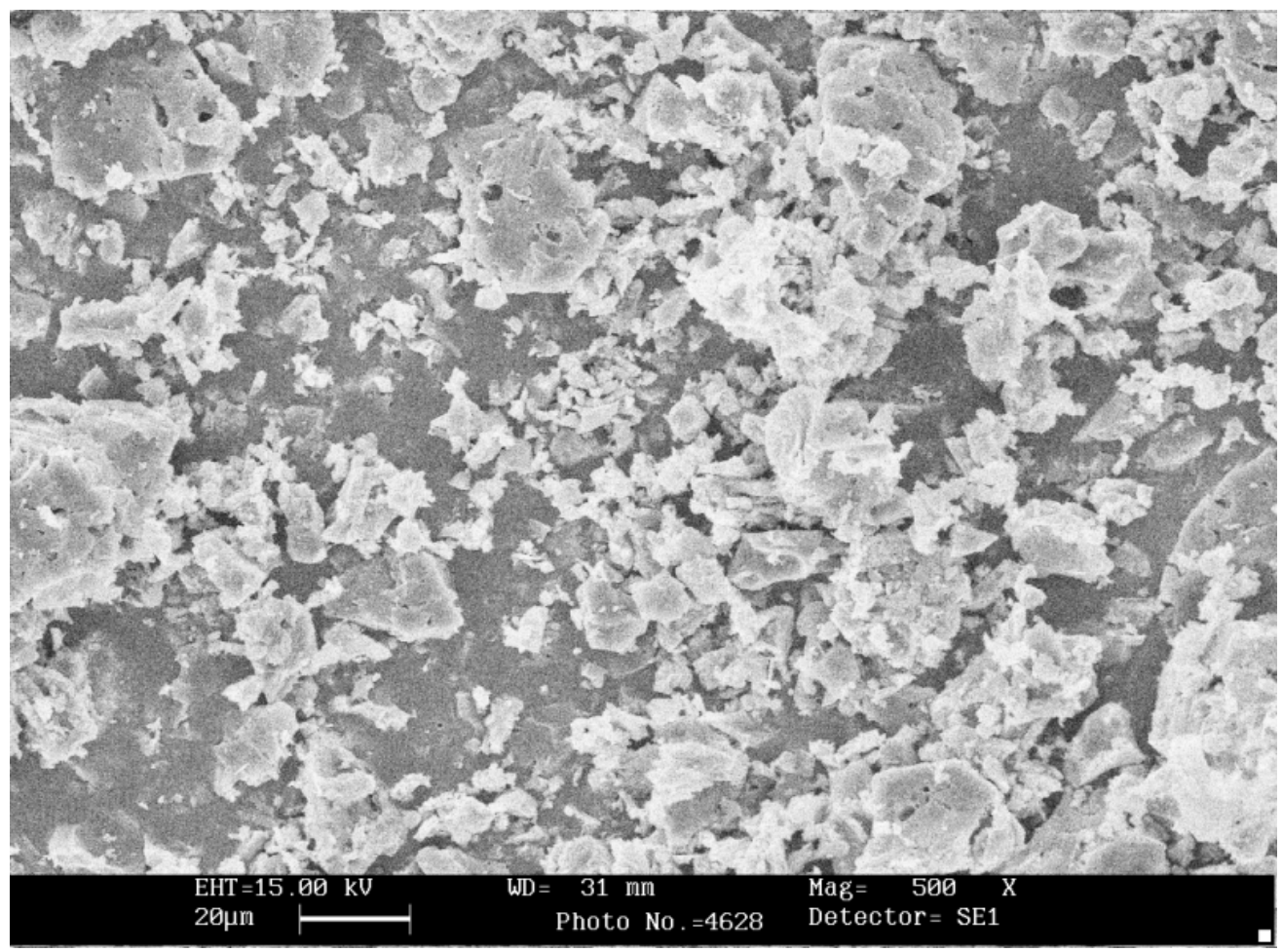

(c)

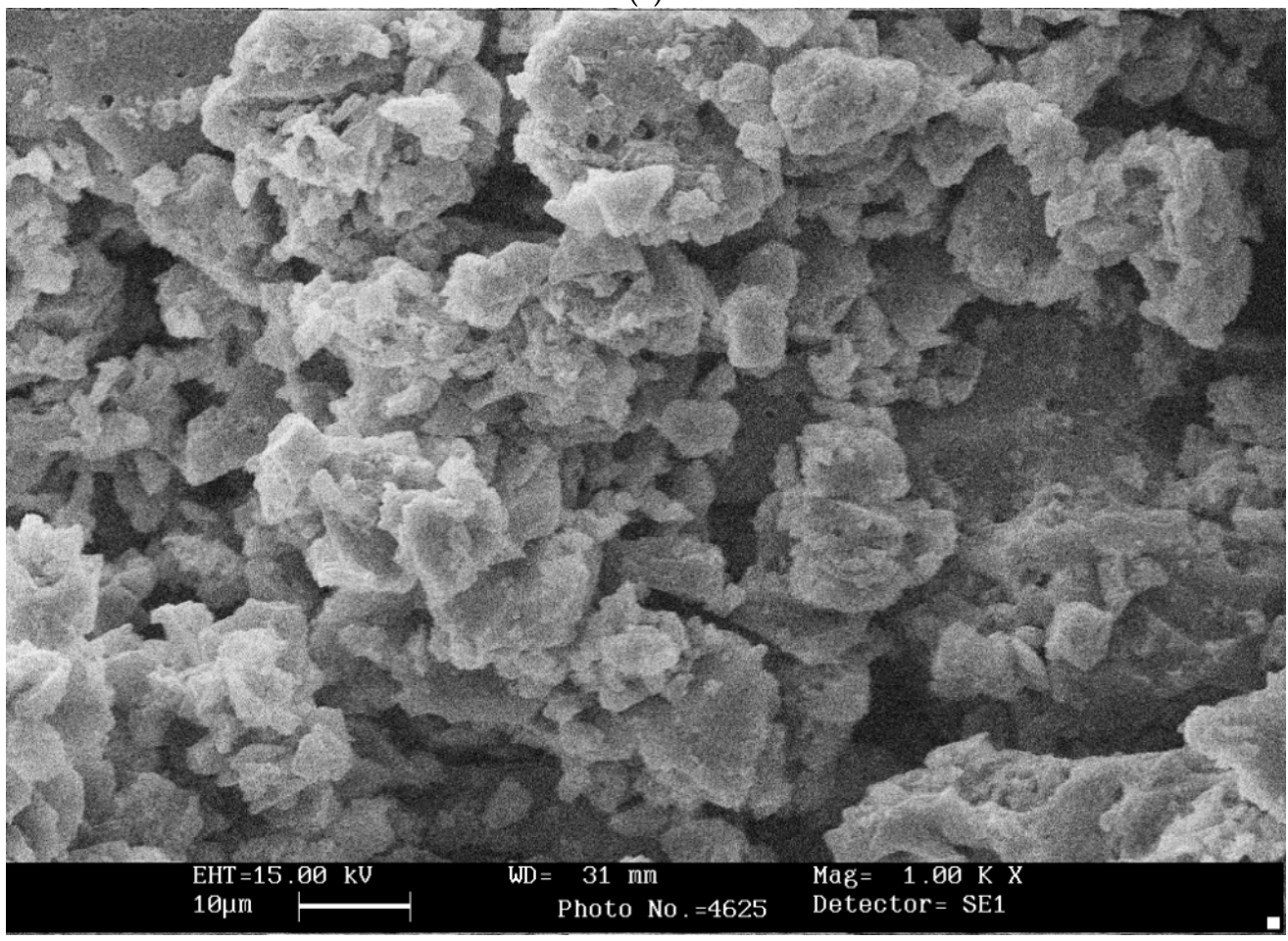

(d)

Figure 5. (a-d) Scanning electron micrographs (magnification 10,000×) of (a) PSW, (b) TSW, (c) MSW and (d) HSW biochars. 


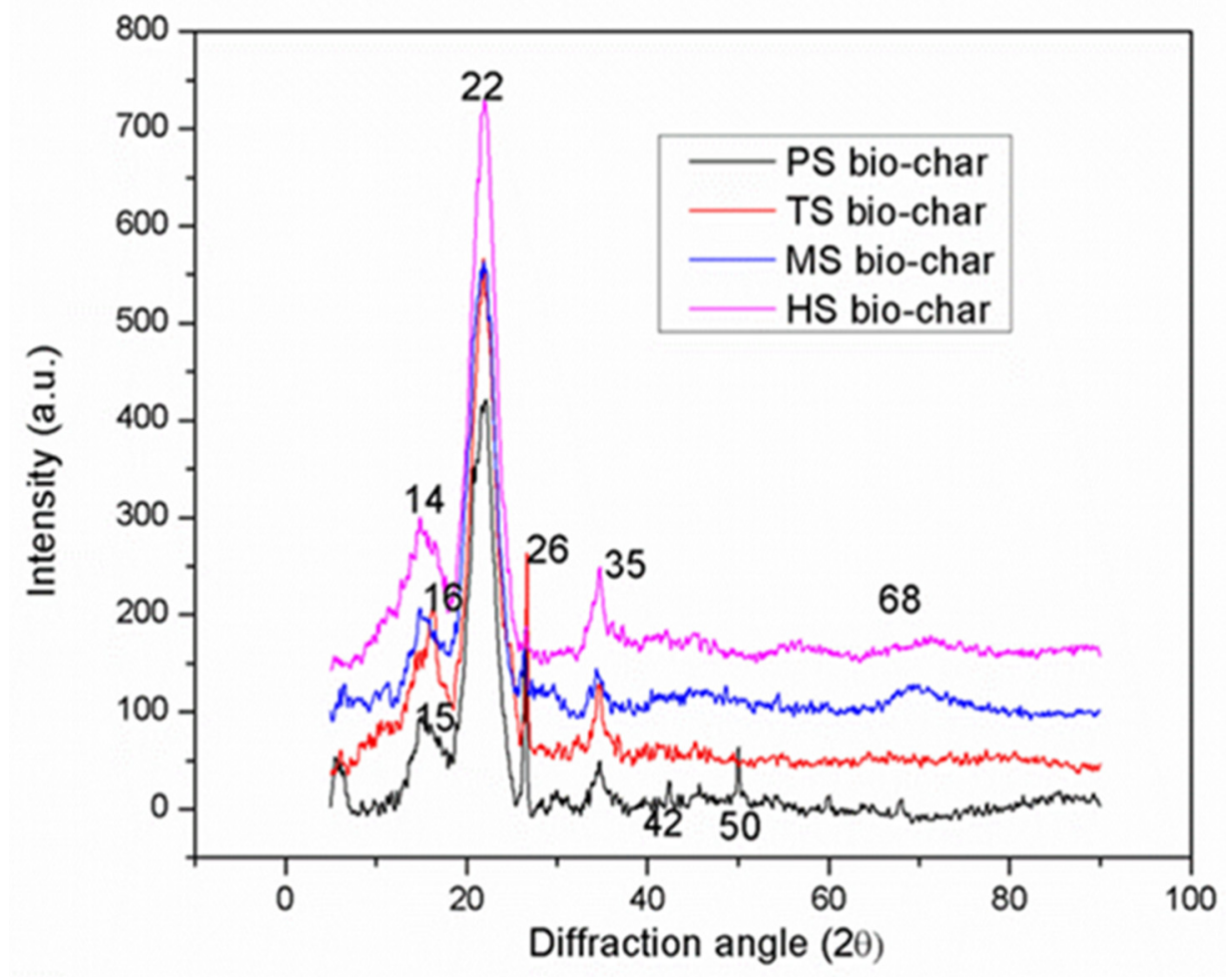

Figure 6. XRD of the different types of bio-char.

\subsection{FTIR of Bio-Char}

Functional group analysis of various bio-char products, obtained using FTIR spectroscopy, is shown in Figure 7, and the band assignment is discussed in Table 3. The FTIR spectrum in the range of $500-4500 \mathrm{~cm}^{-1}$ was measured with a resolution of $4 \mathrm{~cm}^{-1}$. Major components of biomass are hemicellulose, cellulose and lignin. Lignin, unlike cellulose, possesses olefinic carbon-carbon $(-\mathrm{C}=\mathrm{C}-$ ) double bond in cyclic as well as side chains and is aromatic in nature [68]. The band peaks at the wave numbers of 3465, 3428, 3411 and $3442 \mathrm{~cm}^{-1}$ are for PSW, TSW, MSW and HSW bio-chars, respectively, which indicated the stretching vibration of- $\mathrm{OH}$ hydroxyl groups of phenol. The second prominent peaks are at 3050 and $2849 \mathrm{~cm}^{-1}$, and $3075,2925 \mathrm{~cm}^{-1}$, only shown by TSW and MSW bio-chars, which represent the $-\mathrm{CH}$ stretching vibrations due to the presence of methyl/methylene group. The peak at $1587 \mathrm{~cm}^{-1}$ represents the aromatic $\mathrm{C}=\mathrm{C}$ ring stretching vibration of lignin. The medium band intensity between $1398-1401 \mathrm{~cm}^{-1}$ may be assigned to aromatic skeleton vibrations combined with $\mathrm{C}-\mathrm{H}$ in plane deformations of bio-chars. The band peak at $1265 \mathrm{~cm}^{-1}$ of PSW bio-char confirmed the presence of aromatic $\mathrm{CO}-$ and phenolic $-\mathrm{OH}$ stretching due to the presence of cellulose, hemi-cellulose and lignin. The $750 \mathrm{~cm}^{-1} \mathrm{band}$ peak showed 3-4 adjacent $\mathrm{H}$ deformation of all bio-char samples except TSW bio-char.

From Figure 7 it can be concluded that the different peaks for different bio-char samples are almost similar. A drift of wave number from alower to higher value was due to an increase in temperature, which indicated more carbon content of the char. The wave number from 3400 to $3460 \mathrm{~cm}^{-1}$ indicated low frequency values between these peaks, suggested that hydroxyl groups are involved in hydrogen bonding. The non-involving $\mathrm{OH}$ bonds were above $3500 \mathrm{~cm}^{-1}$ for other groups (i.e., alcohols, phenols and carboxylic acid). Hemicelluloses and celluloses components are broken completely; it goes into either gases or liquid products. The peaks in the range of $1585-1127 \mathrm{~cm}^{-1}$ indicated the presence of hemi-cellulose components. The holo-cellulose (cellulose+hemi-cellulose) structure will collapse after wave number gets reduced. The band intensities were decreased at $3411 \mathrm{~cm}^{-1}$ (O-H stretching) and $1127 \mathrm{~cm}^{-1}$ (C-O stretching) due to the existence of a hydrogen bond, reduction of water and cellulose contents in bio-char. The band intensity of the absorbance of the $-\mathrm{OH}$ decreased. Due to complete loss of alcoholic or phenolic groups, 
the oxygen:carbon ratio of the char decreased. Further, due to high rigid structure lignin was remain within the carbon chain at 1400 to $750 \mathrm{~cm}^{-1}$ in the bio-char, while unconverted lignin remains within the bio-char. Similar observations were reported for different biochars in the literature $[64,68-70]$.

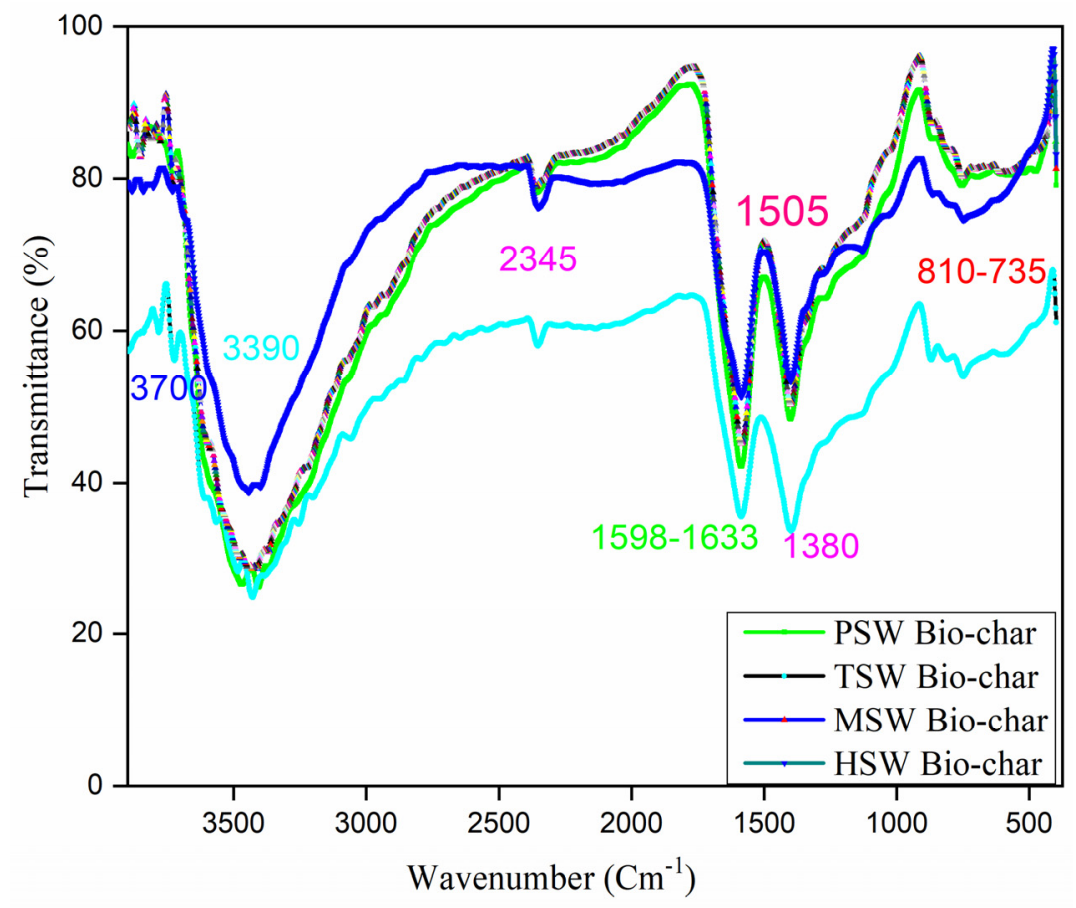

Figure 7. Infrared spectra of the different bio-chars.

Table 3. FTIR band assignments spectra of different types of bio-chars at $375^{\circ} \mathrm{C}$.

\begin{tabular}{|c|c|c|c|c|}
\hline \multirow{2}{*}{ Band Assignment } & \multicolumn{4}{|c|}{ Band Frequency $\left(\mathrm{cm}^{-1}\right)$} \\
\hline & PSW & TSW & MSW & HSW \\
\hline $\mathrm{O}-\mathrm{H}$ stretching & 3465 & 3428 & 3411 & 3442 \\
\hline $\mathrm{C}-\mathrm{H}$ stretching & - & 3050,2849 & 3075,2925 & - \\
\hline $\begin{array}{l}\text { Aromatic vibrations of } \\
C-C / C=C \text { stretching }\end{array}$ & 1587 & 1585 & 1585 & 1586 \\
\hline $\begin{array}{l}\mathrm{C}-\mathrm{O}-\mathrm{H} \text { in-plane bending and } \\
\text { aromatic vibrations }\end{array}$ & 1401 & 1398 & 1400 & 1399 \\
\hline $\begin{array}{l}\mathrm{OH} \text { bending and } \mathrm{CH} \\
\text { deformation vibrations }\end{array}$ & 1265 & - & 1265 & 1265 \\
\hline $\begin{array}{c}\mathrm{C}-\mathrm{H} \text { in-plane deformation and } \\
\mathrm{C}-\mathrm{OH} \text { stretch in syringyl }\end{array}$ & 1121 & 1124 & 1124 & 1127 \\
\hline $\mathrm{O}-\mathrm{CH}_{3}$ and $\mathrm{C}-\mathrm{OH}$ stretching & - & - & 1021 & 1015 \\
\hline \multirow{2}{*}{ C-H out-of-plane stretching } & 868 & 870,806 & 865,803 & 868 \\
\hline & 750 & 750 & 747 & 750 \\
\hline
\end{tabular}

3.5. Surface Area, Total Pore Volume, Average Pore size Volume, $p H$ and its Potential Applications

The surface area, total pore volume, average pore size volume and $\mathrm{pH}$ values of different bio-chars, shown in Table 4, are significant like other physical and chemical characteristics. It may strongly influence the combustion and reactive behavior of the bio-char. The bio-chars produced at pyrolysis temperature of $375^{\circ} \mathrm{C}$ develop high porosity in the surface of bio-chars which emerged macro and micro porous particles. This occurs due to removal of volatile 
matters from different biomass residues [71]. Due to opportunity of high pores surface area and adsorption sites which contributes to adsorptive capacity and also provides spaces for nutrients/pollutants and water retention [53] in soil treatment applications.

For different bio-chars investigated in the present work, BET surface areas are found as $40-58 \mathrm{~m}^{2} / \mathrm{g}$, at particle size and heating rate $+1.5-2.5$, and $20{ }^{\circ} \mathrm{C} / \mathrm{min}$, respectively, for paper-, thin-, medium- and hard-shelled walnuts, at temperature of $375^{\circ} \mathrm{C}$. With an increasing temperature, reduction in the surface area values are predominantly detected, as shown in Table 4. The fusion of adjacent pores seems to predominate, leading to the decline in the surface area and thermal deactivation of the bio-chars. The bio-chars used in the present work have higher surface area and some others were comparable with the investigation reported by other examiners (Table 4) for different biomass residues [72-76]. The highest and lowest surface areas are in HSW and PSW bio-chars, respectively. Due to high BET surface area and quality of bio-chars, it could have high adsorption capacity. For the application of bio-char in wastewater treatment and soil remediation, the BET surface area and quality of bio-chars can be further enhanced by alkaline and acid treatment. Moreover, it can be transformed to activated carbon for water purification processes and in fuel utilities.

Pyrolysis of biomass involves eradication of organic/volatile matters, which enhances the alkali concentration [77]. The $\mathrm{pH}$ plays an important role for soil fertility, which effects the types of plants, availability of nutrients and microbes to be consumed [52]. The $\mathrm{pH}$ is found in between 8.1-8.3 for all types of bio-chars, respectively. All bio-char samples showed alkaline characteristics, and may be used for soil amendment to neutralize soil acidity, and also enhances the soil quality and improves the yield productivity [78]. Similar results have also been made by other investigators and are comparable with the obtained results, as reported in Table 4 .

\subsection{Circular Economy Models}

The circular bio-economy is a concept for the transformation and management of land, food, health and industrial systems using renewable natural capital. It has the aim of achieving sustainable wellbeing in concord with nature. The prosperity of the recycling-based bioeconomy requires modern technology, innovation, traditional wisdom and biodiversity. That is ultimately the fundamental driving force for bioeconomy. Further, biodiversity affects the ability of biological systems to adapt to changing environments. Thus, it become important to ensure the resilience and sustainability of biological resources. It must be recognized its importance not only through proper nature maintenance policies, but also through locally adapted market-based means that encourage farmers, forest owners and bio-based companies to invest in biodiversity. Since the industrial revolution, human activity has been a major cause of global environmental change. Humans and the environment have a skewed connection, which has resulted in faced thresholds and turning points connected with planetary boundaries, such as biodiversity loss and the global climate catastrophe [84]. A sustainable bioeconomy also encompasses more than just the interchange of fossil and renewable resources. Low-carbon energy, sustainable supply chains, and promising disruptive conversion technologies are all required for the long-term conversion of renewable energy resources into high-quality bio-based goods, materials and fuels. The natural environment, human health and natural resources are one of the activities [85]. Circular economy means that it is fundamentally different from person to person. It has basically become an "essentially controversial concept". This is a phrase created by Gallie [86], and although there is consensus on the means and purpose of the concept, there is disagreement on its definition. Recently used to characterize the concept of the circular economy [87], the European Commission's bioeconomic strategy interprets the circulating bioeconomy as a framework for reducing dependence on natural resources. Manufacturing transformation: Promote sustainable production of renewable resources from land, fisheries and aquaculture. It will drive the transition to a variety of bio-based products and bioenergy while creating new jobs and industries [88]. On the one hand, 
circular economy focuses on increasing efficiency and reducing speed, reducing and closing hardware loops to reduce resource consumption and system waste through reduced inputs, sustainable design, practice improvement, reuse and waste recycling $[89,90]$. In accordance with circular bioeconomy concepts, the bio-char was prepared form different walnut shells as a biomass residue at different temperatures, particle sizes and heating rates. The smaller particle size was considered as there may be higher temperature gradient in larger particles, which results into non-uniform heat distribution in the biomass particle. The different bio-chars showed high carbon (73.4-82.7) and lower nitrogen contents with high heating values (14.8 to $18.4 \mathrm{MJ} / \mathrm{kg}$ ), which enhanced bio-char qualities and is comparable to high quality lignite coal, and, therefore, can be utilized as a renewable solid fuel.

Table 4. Surface area, total pore volume, average pore size volume and $\mathrm{pH}$ values of WS bio-chars with different temperatures, at $1.5-2.5 \mathrm{~mm}$ particle size and $20^{\circ} \mathrm{C} / \mathrm{min}$ heating value.

\begin{tabular}{|c|c|c|c|c|c|c|}
\hline $\begin{array}{l}\text { Bio-Char Types } \\
\text { (Pyrolysis } \\
\text { Temperature) }\end{array}$ & $\begin{array}{c}\text { BET } \\
\text { Surface } \\
\text { Areas } \\
\left(\mathrm{m}^{2} / \mathrm{g}\right)\end{array}$ & $\begin{array}{l}\text { Total Pore } \\
\text { Volume } \\
\mathrm{cm}^{3} / \mathrm{g}\end{array}$ & $\begin{array}{l}\text { Average } \\
\text { Pore Size } \\
\text { (A) }\end{array}$ & $\mathrm{pH}$ & Applications & References \\
\hline PSW & 42 & 0.012 & 17 & 8.4 & \multirow{4}{*}{$\begin{array}{l}\text { Fuel, energy storage, soil conditioner, building } \\
\text { sector, drinking and wastewater treatments, } \\
\text { biogas production, exhaust filters, industrial } \\
\text { materials, electronics semiconductors, } \\
\text { cosmetics, paints and coloring }\end{array}$} & \multirow{4}{*}{ Present work } \\
\hline TSW & 44 & 0.013 & 18 & 8.2 & & \\
\hline MSW & 48 & 0.014 & 19 & 8.1 & & \\
\hline HSW & 58 & 0.016 & 19.5 & 8.3 & & \\
\hline $\begin{array}{l}\text { Sugarcane bagasse } \\
\left(500^{\circ} \mathrm{C}\right)\end{array}$ & 10.85 & 0.011 & 43.7 & 8.1 & Solid fuel, adsorbent, soil amendment & {$[53]$} \\
\hline $\begin{array}{l}\text { Apricot kernel shell } \\
\left(550^{\circ} \mathrm{C}\right)\end{array}$ & 195 & 0.1124 & - & - & $\begin{array}{l}\text { Activated carbon, fuel applications, water } \\
\text { purification, adsorption }\end{array}$ & [19] \\
\hline Rice straw $\left(600^{\circ} \mathrm{C}\right)$ & 4.76 & 0.0023 & 18.74 & - & $\begin{array}{l}\text { Adsorption Water purification, activated } \\
\text { carbon, fuel applications }\end{array}$ & {$[74]$} \\
\hline Coconut fiber $\left(600^{\circ} \mathrm{C}\right)$ & 23.2 & 0.04 & & 9.6 & $\begin{array}{c}\text { Sequester carbon in soils, improving soil } \\
\text { quality and plant growth }\end{array}$ & [17] \\
\hline $\begin{array}{l}\text { Flax straw } \\
\left(550{ }^{\circ} \mathrm{C}\right)\end{array}$ & 28.7 & 0.009 & 37.5 & - & $\begin{array}{l}\text { Soil amendment, carbon sequestration, } \\
\text { activated chars. }\end{array}$ & {$[72]$} \\
\hline $\begin{array}{c}\text { Wood } \\
\left(450^{\circ} \mathrm{C}\right)\end{array}$ & 23 & & & 6.7 & $\begin{array}{l}\text { Soil reduced the } C \text {-mineralization rate } \\
\text { compared against the control soil samples }\end{array}$ & {$[75]$} \\
\hline Paddy Straw $\left(500^{\circ} \mathrm{C}\right)$ & 45.8 & & & 10.5 & $\begin{array}{l}\text { Fertilizer consumption reduced, and } \\
\text { sequestrate carbon }\end{array}$ & [76] \\
\hline $\begin{array}{l}\text { Durian wood sawdust } \\
\qquad\left(450^{\circ} \mathrm{C}\right)\end{array}$ & 45.78 & 5.786 & 80.98 & 6.4 & $\begin{array}{l}\text { Provide suitable proportions for developing } \\
\text { clusters of microorganisms, water retention } \\
\text { capacity in soil and enhances soil fertility. }\end{array}$ & {$[79]$} \\
\hline $\begin{array}{l}\text { Spent P. ostreatus } \\
\quad\left(500^{\circ} \mathrm{C}\right)\end{array}$ & 18.05 & 0.061 & 136 & 10.37 & $\begin{array}{l}\text { Potential adsorbent for removing heavy metals } \\
\text { from wastewater }\end{array}$ & [80] \\
\hline $\begin{array}{c}\text { Corn stalk } \\
\left(450{ }^{\circ} \mathrm{C}\right)\end{array}$ & 57.80 & 0.081 & 49.1 & & $\begin{array}{l}\text { Adsorption characteristics and mechanism of } \\
\text { bio-char on nonpolar pollutants }\end{array}$ & [81] \\
\hline $\begin{array}{l}\text { Rice husk } \\
\left(500^{\circ} \mathrm{C}\right)\end{array}$ & 92.6 & 0.076 & 22.0 & & Adsorptive properties & {$[82]$} \\
\hline $\begin{array}{l}\text { Charcoal fines } \\
\quad\left(500^{\circ} \mathrm{C}\right)\end{array}$ & $43 \pm 3$ & 0.035 & & & $\begin{array}{l}\text { Water retention capacities and cation } \\
\text { exchange capacity }\end{array}$ & [83] \\
\hline
\end{tabular}

\section{Conclusions}

Persistent environmental problems, rising oil prices, energy crisis, depletion of fossil fuels, and growing application and demand for energy are important reasons why people are resolute in demanding energy sources and alternative sustainable fuels. For the environment, sustainability and biodegradability are key characteristics that make biomass a prime candidate for bioenergy production. Bio-char has the ability to sequester carbon in the soil, while improving plant growth and soil quality, with high energy density. Further, it can also be used as an adsorbent for water treatment. In the present study, the characterization 
of four different bio-chars, obtained by slow pyrolysis at $375{ }^{\circ} \mathrm{C}$, produced from hard, medium, thin seed residues and paper peels was investigated. The properties of biochar, such as proximate and ultimate analysis, heating value, surface area, $\mathrm{pH}$ value, thermal degradation behavior, morphological and crystalline nature and functional characterization using FTIR, were determined. The key outcome from the present work can be summarized as follows;

- The pyrolytic behavior of bio-char was studied using thermogravimetric analysis (TGA) in an oxidizing atmosphere. SEM analysis confirmed morphological change and showed heterogeneous and rough texture structure.

- Crystalline nature of the bio-chars was established by X-ray powder diffraction (XRD) analysis. The maximum higher heating values (HHV), high fixed carbon content and surface area obtained for walnut shells (WS) samples were found as $\sim 18.4 \mathrm{MJ} \mathrm{kg}^{-1}$, $>80 \%$ and $58 \mathrm{~m}^{2} / \mathrm{g}$, respectively.

- Improvement in $\mathrm{HHV}$ and decrease of $\mathrm{O} / \mathrm{C}$ and $\mathrm{H} / \mathrm{C}$ ratios led the bio-char samples to fall into the category of coal and confirmed their hydrophobic, carbonized and aromatized nature.

- From the Fourier transform infra-red spectroscopy (FTIR), it was observed that there was alteration in functional groups with an increase in temperature, and illustrated higher aromaticity. Therefore, it could be concluded that the bio-char obtained from walnut shell has a high potential to be used as an efficient fuel in both industrial as well as domestic furnaces for energy production.

- Further, from surface area and $\mathrm{pH}$ analysis of bio-chars, it was found that WS bio-chars had similar characteristics to adsorbents used for water purifications, retention of essential elements in soil and carbon sequestration.

- The improvement in characteristics of different bio-chars, as compared to their respective biomass residues, showed that it may also be used as a good adsorbent for wastewater treatment as well as for enhancing soil fertility.

Author Contributions: Conceptualization, M.A.S. and R.A.; methodology, M.A.S. and M.I.H.S.; formal analysis, M.A.S., M.A.A. and I.A.A.; investigation, M.A.S., M.A.A. and I.A.A.; resources, M.A.S. and R.A.; writing-original draft preparation, M.A.S. and M.I.H.S.; writing-review and editing, M.A.S., R.A., M.A.A., I.A.A. and M.I.H.S. All authors have read and agreed to the published version of the manuscript.

Funding: The authors express their appreciation to the Deputyship for Research and Innovation, Ministry of education in Saudi Arabia for funding this research work through the project number 20-UQU-IF-P2-001.

Institutional Review Board Statement: Not applicable.

Informed Consent Statement: Not applicable.

Data Availability Statement: Not applicable.

Acknowledgments: We are thankful to the Deputyship for Research and Innovation, Ministry of education in Saudi Arabia for funding this research work through the project number 20-UQU-IF-P2-001.

Conflicts of Interest: The authors declare no conflict of interest.

\section{References}

1. Jia, Y.; Wang, Y.; Zhang, Q.; Rong, H.; Liu, Y.; Xiao, B.; Guo, D.; Laghari, M.; Ruan, R. Gas-carrying enhances the combustion temperature of the biomass particles. Energy 2021, 239, 121956. [CrossRef]

2. Hansson, A.; Haikola, S.; Fridahl, M.; Yanda, P.; Mabhuye, E.; Pauline, N. Biochar as multi-purpose sustainable technology: Experiences from projects in Tanzania. Environ. Dev. Sustain. 2021, 23, 5182-5214. [CrossRef]

3. Masek, O.; Brownsort, P.; Cross, A.; Sohi, S. Influence of production conditions on the yield and environmental stability of biochar. Fuel 2013, 103, 151-155. [CrossRef]

4. Manya, J.J. Pyrolysis for biochar purposes: A review to establish current knowledge gaps and research needs. Environ. Sci. Technol. 2012, 46, 7939-7954. [CrossRef] [PubMed] 
5. Kane, S.N.; Mishra, A.; Dutta, A.K. Preface: International Conference on Recent Trends in Physics (ICRTP 2016). J. Phys. Conf. Ser. 2016, 755, 5. [CrossRef]

6. Ciolkosz, D.; Wallace, R. A review of torrefaction for bioenergy feedstock production. Biofuels Bioprod. Biorefin. 2011, 5, 317-329. [CrossRef]

7. Liu, Z.; Han, G. Production of solid fuel biochar from waste biomass by low temperature pyrolysis. Fuel 2015, 158, 159-165. [CrossRef]

8. Chen, W.-H.; Lin, B.-J.; Colin, B.; Chang, J.-S.; Pétrissans, A.; Bi, X.; Pétrissans, M. Hygroscopic transformation of woody biomass torrefaction for carbon storage. Appl. Energy 2018, 231, 768-776. [CrossRef]

9. Zhu, X. Effects and mechanisms of biochar-microbe interactions in soil improvement and pollution remediation: A review. Environ. Pollut. 2017, 227, 98-115. [CrossRef]

10. Oliveira, F.R.; Patel, A.K.; Jaisi, D.P.; Adhikari, S.; Lu, H.; Khanal, S.K. Environmental application of biochar: Current status and perspectives. Bioresour. Technol. 2017, 246, 110-122. [CrossRef]

11. Xu, G.; Lv, Y.; Sun, J.; Shao, H.; Wei, L. Recent Advances in Biochar Applications in Agricultural Soils: Benefits and Environmental Implications. Clean Soil Air Water 2012, 40, 1093-1098. [CrossRef]

12. Zhao, L.; Cao, X.; Masek, O.; Zimmerman, A. Heterogeneity of biochar properties as a function of feedstock sources and production temperatures. J. Hazard. Mater. 2013, 256-257, 1-9. [CrossRef]

13. Gupta, S.; Kua, H.W.; Low, C.Y. Low, Use of biochar as carbon sequestering additive in cement mortar. Cem. Concr. Compos. 2018, 87, 110-129. [CrossRef]

14. Gan, Y.Y. Torrefaction of microalgal biochar as potential coal fuel and application as bio-adsorbent. Energy Convers. Manag. 2018, 165, 152-162. [CrossRef]

15. Lee, H.W.; Kim, Y.M.; Kim, S.; Ryu, C.; Park, S.H.; Park, Y.-K. Review of the use of activated biochar for energy and environmental applications. Carbon Lett. 2018, 26, 1-10.

16. Chen, W.; Lee, K.T.; Chih, Y.K.; Eng, C.; Lin, H.P.; Chiou, Y.B.; Cheng, C.L.; Lin, Y.X.; Chang, J.S. Novel Renewable Double-Energy System for Activated Biochar Production and Thermoelectric Generation from Waste Heat. Energy Fuels 2020, 34, 3383-3393. [CrossRef]

17. Windeatt, J.H.; Ross, A.B.; Williams, P.T.; Forster, P.M.; Nahil, M.A.; Singh, S. Characteristics of biochars from crop residues: Potential for carbon sequestration and soil amendment. J. Environ. Manag. 2014, 146, 189-197. [CrossRef]

18. Moreira, R.; Vaz, J.M.; Spinace, E.V.; dos Reis Orsini, R.; Penteado, J.C. Production of Biochar, Bio-Oil and Synthesis Gas from Cashew Nut Shell by Slow Pyrolysis. Waste Biomass Valorization 2016, 8, 217-224. [CrossRef]

19. Demiral, I.; Kul, S.C. Pyrolysis of apricot kernel shell in a fixed-bed reactor: Characterization of bio-oil and char. J. Anal. Appl. Pyrolysis 2014, 107, 17-24. [CrossRef]

20. Jiang, K.-M.; Cheng, C.-G.; Ran, M.; Lu, Y.-G.; Wu, Q.-L. Preparation of a biochar with a high calorific value from chestnut shells. New Carbon Mater. 2018, 33, 183-187. [CrossRef]

21. Yaashikaa, P.R.; Kumar, P.S.; Varjani, S.; Saravanan, A. A critical review on the biochar production techniques, characterization, stability and applications for circular bioeconomy. Biotechnol. Rep. 2020, 28, e00570. [CrossRef] [PubMed]

22. Lu, H.R.; El Hanandeh, A. Life cycle perspective of bio-oil and biochar production from hardwood biomass; what is the optimum mix and what to do with it? J. Clean. Prod. 2019, 212, 173-189. [CrossRef]

23. Kim, M.; Park, J.; Yu, S.; Ryu, C.; Park, J. Clean and energy-efficient mass production of biochar by process integration: Evaluation of process concept. Chem. Eng. J. 2019, 355, 840-849. [CrossRef]

24. Wang, J.; Wang, S. Preparation, modification and environmental application of biochar: A review. J. Clean. Prod. 2019, $227,1002-1022$. [CrossRef]

25. Gurwick, N.P.; Moore, L.A.; Kelly, C.; Elias, P. A systematic review of biochar research, with a focus on its stability in situ and its promise as a climate mitigation strategy. PLoS ONE 2013, 8, e75932. [CrossRef]

26. Marmiroli, M.; Bonas, U.; Imperiale, D.; Lencioni, G.; Mussi, F.; Marmiroli, N.; Maestri, E. Structural and functional features of chars from different biomasses as potential plant amendments. Front Plant Sci. 2018, 9, 1119. [CrossRef]

27. Ghodake, G.S.; Shinde, S.K.; Kadam, A.A.; Saratale, R.G.; Saratale, G.D.; Kumar, M.; Palem, R.R.; AL-Shwaiman, H.A.; Elgorban, A.M.; Syed, A. Review on biomass feedstocks, pyrolysis mechanism and physicochemical properties of biochar: State-of-the-art framework to speed up vision of circular bioeconomy. J. Clean. Prod. 2020, 297, 126645. [CrossRef]

28. Lin, Y.L.; Zheng, N.Y.; Hsu, C.H. Torrefaction of fruit peel waste to produce environmentally friendly biofuel. J. Clean. Prod. 2020, 284, 124676. [CrossRef]

29. Romanowska-Duda, Z.; Szufa, S.; Grzesik, M.; Piotrowski, K.; Janas, R. The Promotive Effect of Cyanobacteria and Chlorella sp. Foliar Biofertilization on Growth and Metabolic Activities of Willow (Salix viminalis L.) Plants as Feedstock Production, Solid Biofuel and Biochar as C Carrier for Fertilizers via Torrefaction Process. Energies 2021, 14, 5262. [CrossRef]

30. D'Adamo, I.; Morone, P.; Huisingh, D. Bioenergy: A Sustainable Shift. Energies 2021, 14, 5661. [CrossRef]

31. $\mathrm{Xu}, \mathrm{T}$.; Bhattacharya, S. Mineral transformation and morphological change during pyrolysis and gasification of victorian brown coals in an entrained flow reactor. Energy Fuels 2019, 33, 6134-6147. [CrossRef]

32. Li, J.; Du, Y.; Bao, T.; Dong, J.; Lin, M.; Shim, H.; Yang, S.-T. n-Butanol production from lignocellulosic biomass hydrolysates without detoxification by Clostridium tyrobutyricum Dack-adhE2 in a fibrous-bed bioreactor. Bioresour. Technol. 2019, $289,121749$. [CrossRef] 
33. Zabed, H.; Sahu, J.N.; Boyce, A.N.; Faruq, G. Fuel ethanol production from lignocellulosic biomass: An overview on feedstocks and technological approaches. Renew. Sustain. Energy Rev. 2016, 66, 751-774. [CrossRef]

34. Zhang, P.; Guo, Y.J.; Chen, J.; Zhao, Y.R.; Chang, J.; Junge, H.; Beller, M.; Li, Y. Streamlined hydrogen production from biomass. Nat. Cat. 2018, 1, 332-338. [CrossRef]

35. Sette, J.R.; Hansted, C.R.; Novaes, A.L.S.; Lima, E.; Rodrigues, P.A.F.; Santos, A.C.; Yamaji, D.R.S. Energy enhancement of the eucalyptus bark by briquette production. Ind. Crops. Prod. 2018, 122, 209-213. [CrossRef]

36. The International Nut and Dried Fruit Council Foundation, Stastical Year Book 2017-2018. Available online: https: / www.nutfruit. org/files/tech/1524481168_INC_Statistical_Yearbook_2017-2018.pdf (accessed on 20 June 2021).

37. Shah, M.A.; Khan, M.N.S.; Kumar, V. Biomass residue characterization for their potential application as biofuels. J. Therm. Anal. Calorim. 2018, 134, 2137-2145. [CrossRef]

38. ASTM E 871-82; Moisture Analysis of Particulate Wood Fuels; ASTM: West Conshohocken, PA, USA, 2014. [CrossRef]

39. ASTM D1102-84; Standard Test Method for Ash in Wood; ASTM: West Conshohocken, PA, USA, 2013. [CrossRef]

40. EN 14175-3:2003; Fume Hoods-Type Test Methods; National Standards Association Ireland: Dublin, Ireland, 2003. [CrossRef]

41. Chowdhury, Z.Z.; Pal, K.; Johan, R.B.; Yehye, W.; Ali, M.E. Comparative Evaluation of Physiochemical Properties of a Solid Fuel Derived from Adansonia digitata Trunk Using Torrefaction. Bioresources 2017, 12, 3816-3833. [CrossRef]

42. Liu, Z.; Quek, A.; Kent, H.S.; Balasubramanian, R. Production of solid biochar fuel from waste biomass by hydrothermal carbonization. Fuel 2013, 103, 943-949. [CrossRef]

43. ASTM D5373-08; Standard Test Methods for Instrumental Determination of Carbon, Hydrogen, and Nitrogen in Laboratory Samples of Coal; ASTM: West Conshohocken, PA, USA, 2012. [CrossRef]

44. ASTM D2015-85; Standard Test Method for Gross Calorific Value of Coal and Coke by the Adiabatic Bomb Calorimeter; ASTM: West Conshohocken, PA, USA, 1975.

45. Gonzalez, J.F.; Ramiro, A.; Gonzalez-Garcia, C.M.; Ganan, J.; Encinar, J.M.; Sabio, E.; Rubiales, J. Pyrolysis of almond shells. Energy applications of fractions. Ind. Eng. Chem. Res. 2005, 44, 3003-3012. [CrossRef]

46. Nanda, S.; Mohanty, P.; Pant, K.K.; Naik, S.; Kozinski, J.A.; Dalai, A.K. Characterization of North American Lignocellulosic Biomass and Biochars in Terms of their Candidacy for Alternate Renewable Fuels. Bioenergy Res. 2013, 6, 663-677. [CrossRef]

47. McKendry, P. Energy production from biomass (part 1): Overview of biomass. Bioresour. Technol. 2002, 83, 37-46. [CrossRef]

48. Yang, Y.; Brammer, J.G.; Mahmood, A.S.N.; Hornung, A. Intermediate pyrolysis of biomass energy pellets for producing sustainable liquid, gaseous and solid fuels. Bioresour. Technol. 2014, 169, 794-799. [CrossRef]

49. Onay, O.; Beis, S.H.; Kockar, O.M. Pyrolysis of walnut shell in a well-swept fixed-bed reactor. Energy Sources 2004, 26, 771-782. [CrossRef]

50. Mukome, F.N.D.; Zhang, X.; Silva, L.C.R.; Six, J.; Parikh, S.J. Use of chemical and physical characteristics to investigate trends in biochar feedstocks. J. Agric. Food Chem. 2013, 61, 2196-2204. [CrossRef]

51. Rather, M.A.; Khan, N.S.; Gupta, R. Hydrothermal carbonization of macrophyte Potamogeton lucens for solid biofuel production: Production of solid biofuel from macrophyte Potamogeton lucens. Eng. Sci. Technol. Int. J. 2017, 20, 168-174.

52. Varma, A.K.; Mondal, P. Physicochemical characterization and kinetic study of pine needle for pyrolysis process. J. Therm. Anal. Calorim. 2016, 124, 487-497. [CrossRef]

53. Varma, A.K.; Mondal, P. Pyrolysis of sugarcane bagasse in semi batch reactor: Effects of process parameters on product yields and characterization of products. Ind. Crops Prod. 2017, 95, 704-717. [CrossRef]

54. Maiti, S.; Dey, S.; Purakayastha, S.; Ghosh, B. Physical and thermochemical characterization of rice husk char as a potential biomass energy source. Bioresour. Technol. 2006, 97, 2065-2070. [CrossRef] [PubMed]

55. Crombie, K.; Mašek, O.; Brownsort, P.; Sohi, S.P.; Cross, A. The effect of pyrolysis conditions on biochar stability as determined by three methods. GCB Bioenergy 2012, 5, 122-131. [CrossRef]

56. Souza, B.S.; Moreira, A.P.D.; Teixeira, A.M.R.F. TG-FTIR coupling to monitor the pyrolysis products from agricultural residues. J. Therm. Anal. Calorim. 2009, 97, 637-642. [CrossRef]

57. Bisht, A.S.; Kumar, S.R. Use of pine needle in energy generation. Int. J. Res. Appl. Sci. Eng. Technol. 2014, 2, 59-63.

58. Cai, J.M.; Bi, L.S. Kinetic analysis of wheat straw pyrolysis using isoconversional methods. J. Therm. Anal. Calorim. 2009, 98, 325-330. [CrossRef]

59. Chutia, R.S.; Kataki, R.; Bhaskar, T. Thermogravimetric and decomposition kinetic studies of Mesua ferrea L. deoiled cake. Bioresour. Technol. 2013, 139, 66-72. [CrossRef]

60. Mishra, G.; Bhaskar, T. Non isothermal model free kinetics for pyrolysis of rice straw. Bioresour. Technol. 2014, 169, 614-621. [CrossRef]

61. AcIkalIn, K. Pyrolytic characteristics and kinetics of pistachio shell by thermogravimetric analysis. J. Therm. Anal. Calorim. 2012, 109, 227-235. [CrossRef]

62. Lopez-Velazquez, M.A.; Santes, V.; Balmaseda, J.; Torres-Garcia, E. Pyrolysis of orange waste: A thermo-kinetic study. J. Anal. Appl. Pyrolysis 2013, 99, 170-177. [CrossRef]

63. Lapuerta, M.; Hernández, J.J.; Rodríguez, J. Kinetics of devolatilisation of forestry wastes from thermogravimetric analysis. Biomass Bioenergy 2004, 27, 385-391. [CrossRef]

64. Guerrero, M.; Ruiz, M.P.; Millera, A.; Alzueta, M.U.; Bilbao, R. Characteriza-tion of biomass chars formed under different devolatilization conditions: Differences between rice husk and eucalyptus. Energy Fuels 2008, 22, 1275-1284. [CrossRef] 
65. Morin, M.; Pécate, S.; Hémati, M.; Kara, Y. Pyrolysis of biomass in a batch fluidized bed reactor: Effect of the pyrolysis conditions and the nature of the biomass on the physicochemical properties and the reactivity of char. J. Anal. Appl. Pyrolysis 2016, 122, 511-523. [CrossRef]

66. Vassilev, S.V.; Baxter, D.; Andersen, L.K.; Vassileva, C.G.; Morgan, T.J. An overview of the organic and inorganic phase composition of biomass. Fuel 2012, 94, 1-33. [CrossRef]

67. Fu, P.; Hu, S.; Xiang, J.; Sun, L.; Li, P.; Zhang, J.; Zheng, C. Pyrolysis of maize stalk on the characterization of chars formed under different devolatilization conditions. Energy Fuels 2009, 23, 4605-4611. [CrossRef]

68. Sotoudehnia, F.; Baba, R.A.; Alayat, A.; McDonald, A.G. Characterization of bio-oil and biochar from pyrolysis of waste corrugated cardboard. J. Anal. Appl. Pyrolysis 2020, 145, 104722. [CrossRef]

69. Chen, L.; Wang, X.; Yang, H.; Lu, Q.; Li, D.; Yang, Q.; Chen, H. Study on pyrolysis behaviors of non-woody lignins with TG-FTIR and Py-GC / MS. J. Anal. Appl. Pyrolysis 2015, 113, 499-507. [CrossRef]

70. Xu, F.; Yu, J.; Wang, D.; Tesso, T. Qualitative and quantitative analysis of lignocellulosic biomass using infrared techniques: A mini-review. Appl. Energy 2013, 104, 801-809. [CrossRef]

71. Pradhan, D.; Singh, R.K.; Bendu, H.; Mund, R. Pyrolysis of Mahua seed (Madhuca indica)—Production of biofuel and its characterization. Energy Convers. Manag. 2016, 108, 529-538. [CrossRef]

72. Tushar, H.K.; Mahinpey, M.S.; Khan, N.A.; Ibrahim, H.; Kumar, P.; Idem, R. Production, characterization and reactivity studies of chars produced by the isothermal pyrolysis of flax straw. Biomass Bioenergy 2012, 37, 97-105. [CrossRef]

73. Angin, D. Effect of pyrolysis temperature and heating rate on biochar obtainedfrom pyrolysis of safflower seed press cake. Bioresour. Technol. 2013, 128, 593-597. [CrossRef]

74. Fu, P.; Hu, S.; Xiang, J.; Sun, L.; Su, S.; Wang, J. Evaluation of the porous structure development of chars from pyrolysis of rice straw: Effects of pyrolysis temperature and heating rate. J. Anal. Appl. Pyrolysis 2012, 98, 177-183. [CrossRef]

75. Ronsse, F.; van Hecke, S.; Dickinson, D.; Prins, W. Production and characterization of slow pyrolysis biochar: Influence of feedstock type and pyrolysis conditions. GCB Bioenergy 2013, 5, 104-115. [CrossRef]

76. Lee, Y.; Park, J.; Ryu, C.; Gang, K.S.; Yang, W.; Park, Y.; Jung, J.; Hyun, S. Comparison of biochar properties from biomass residues produced by slow pyrolysis at $500^{\circ} \mathrm{C}$. Bioresour. Technol. 2013, 148, 196-201. [CrossRef]

77. Nzihou, A.; Stanmore, B.; Lyczko, N.; Minh, D.P. The catalytic effect of inherent and adsorbed metals on the fast/flash pyrolysis of biomass: A review. Energy 2019, 170, 326-337. [CrossRef]

78. Bordoloi, N.; Narzari, R.; Chutia, R.S.; Bhaskar, T.; Kataki, R. Pyrolysis of Mesua ferrea and Pongamia glabra seed cover: Characterization of bio-oil and its sub-fractions. Bioresour. Technol. 2015, 178, 83-89. [CrossRef] [PubMed]

79. Chowdhury, Z.Z.; Karim, Z.M.; Ashraf, M.A.; Khalid, K. Influence of carbonization temperature on physicochemical properties of biochar derived from slow pyrolysis of durian wood (Durio zibethinus) sawdust. BioResources 2016, 11, 3356-3372. [CrossRef]

80. Wu, Q.; Xian, Y.; He, Z.; Zhang, Q.; Wu, J.; Yang, G. Adsorption characteristics of Pb(II) using biochar derived from spent mushroom substrate. Sci. Rep. 2019, 9, 1-11. [CrossRef]

81. Zhu, L.; Zhao, N.; Tong, L.; Lv, Y. Structural and adsorption characteristics of potassium carbonate activated biochar. RSC Adv. 2018, 8, 21012-21019. [CrossRef]

82. Kwiatkowski, M.; Kalderis, D. A complementary analysis of the porous structure of biochars obtained from biomass. Carbon Lett. 2020, 30, 325-329. [CrossRef]

83. Batista, E.M.C.C.; Shultz, J.; Matos, T.T.S.; Fornari, M.R.; Ferreira, T.M.; Szpoganicz, B. Effect of surface and porosity of biochar on water holding capacity aiming indirectly at preservation of the Amazon biome. Sci. Rep. 2018, 8, 1-9. [CrossRef]

84. Tan, E.C.D. Sustainable Biomass Conversion Process Assessment. In Process Intensification and Integration for Sustainable Design; Foo, D.C.Y., El-Halwagi, M.M., Eds.; John Wiley and Sons, Ltd: Weinheim, Germany, 2021; pp. 301-318.

85. Dewulf, J.; Benini, L.; Mancini, L.; Sala, S.; Blengini, G.A.; Ardente, F.; Recchioni, M.; Maes, J.; Pant, R.; Pennington, D. Rethinking the area of protection "natural resources" in life cycle assessment. Environ. Sci. Technol. 2015, 49, 5310-5317. [CrossRef]

86. Gallie, W.B. IX-Essentially contested concepts. Proc. Arist. Soc. 1956, 56, 167-198. [CrossRef]

87. Korhonen, J.; Nuur, C.; Feldmann, A.; Birkie, S.E. Circular economy as an essentially contested concept. J. Clean. Prod. 2018, 175, 544-552. [CrossRef]

88. European Commission. Bioeconomy. 2013. Available online: https://ec.europa.eu/programmes/horizon2020/en/h2020section/bioeconomy (accessed on 20 November 2013).

89. Bocken, N.M.P.; de Pauw, I.; Bakker, C.; van der Grinten, B. Product design and business model strategies for a circular economy. J. Ind. Prod. Eng. 2016, 33, 308-320. [CrossRef]

90. Tan, E.C.D.; Lamers, P. Circular Bioeconomy Concepts-A Perspective. Front. Sustain. 2021, 2, 701509. [CrossRef] 